\title{
Attitudes and Considerations towards Pharmaceuticals-Related Environmental Issues among Finnish Population
}

\author{
Lasse Alajärvi *, Johanna Timonen, Piia Lavikainen and Janne Martikainen \\ School of Pharmacy, Faculty of Health Sciences, Kuopio Campus, University of Eastern Finland, \\ FI-70211 Kuopio, Finland; johanna.timonen@uef.fi (J.T.); piia.lavikainen@uef.fi (P.L.); \\ janne.martikainen@uef.fi (J.M.) \\ * Correspondence: lasse.alajarvi@uef.fi
}

Citation: Alajärvi, L.; Timonen, J.; Lavikainen, P.; Martikainen, J. Attitudes and Considerations towards Pharmaceuticals-Related Environmental Issues among Finnish Population. Sustainability 2021, 13, 12930. https://doi.org/10.3390/ su132212930

Academic Editors: Simona Gabriela Bungau and Lotfi Aleya

Received: 21 October 2021 Accepted: 19 November 2021 Published: 22 November 2021

Publisher's Note: MDPI stays neutral with regard to jurisdictional claims in published maps and institutional affiliations.

Copyright: (c) 2021 by the authors. Licensee MDPI, Basel, Switzerland. This article is an open access article distributed under the terms and conditions of the Creative Commons Attribution (CC BY) license (https:/ / creativecommons.org/licenses/by/ $4.0 /)$.

\begin{abstract}
A number of policy recommendations identify the general public as a key participant in environmentally sustainable pharmaceutical policies. However, research into pharmaceuticalsrelated environmental issues from the population perspective is scarce. We studied the awareness among Finnish adults $(n=2030)$ of pharmaceutical residues in Finnish waterways, their perceived environmental sources, views on pharmaceuticals-related environmental issues, and their association with background characteristics. Of the respondents, $89.5 \%$ were aware of the presence of pharmaceuticals in Finnish waterways. Wastewaters from the pharmaceutical industry were most frequently, and pharmaceuticals excreted by humans least frequently, considered a major environmental source of pharmaceuticals. The vast majority of the respondents were worried about the environmental and health impact of pharmaceutical residues and emphasized issues such as the importance of environmentally sustainable actions by pharmaceutical companies and the recyclability of the pharmaceutical packaging materials. Age, education, use of prescription medicines, and environmental attitude were associated with awareness of pharmaceutical residues, while gender, age, education level, and environmental attitude were associated most frequently with pharmaceuticals-related environmental considerations. These results indicate a need for improved communication about the environmental effects of pharmaceuticals and the significance of different pharmaceutical emission sources in order to promote a more environmentally friendly, effective pharmaceutical policy.
\end{abstract}

Keywords: pharmaceuticals; environment; survey; population; awareness; attitudes; opinions; latent class analysis

\section{Introduction}

Even though pharmaceuticals play a key role in human well-being, they do have potential adverse effects on both individuals and the environment. Many pharmaceuticals have been found relatively recently to have adverse effects on the environment, and measured environmental concentrations of pharmaceuticals have been reported to an increasing extent from every continent [1]. In consequence, UNESCO has referred to pharmaceuticals as emerging pollutants among other potentially high-risk environmental contaminants [2]. The European Commission took part in the debate on the environmental role of pharmaceuticals when it published the Strategic Approach to Pharmaceuticals in the Environment [3]. The approach includes measures that require the authorities, the pharmaceutical industry, healthcare professionals, and water services as well as the general public to play a part in minimizing the environmental risks of pharmaceuticals during the whole life cycle of a pharmaceutical product. Such communications are an important step towards a more sustainable pharmaceutical sector as they form a common platform for actions and discussion by several stakeholders, including the general public.

To date, it is known from a few examples that pharmaceutical residues can have detrimental effects in the environment. Possibly the best-known examples of these are the destruction of a vulture population in the Indian subcontinent due to diclofenac residues 
in cattle carcasses, and the endocrine-disrupting effects of waterborne residues of synthetic estrogen in fish $[4,5]$. According to a report provided by BIO Intelligence Service for the European Commission, the recognized environmental sources of pharmaceuticals include those excreted by humans and animals, incorrect disposal of medicines, and effluents from the pharmaceutical industry [6]. The report states that $30 \%$ to $90 \%$ of the oral dose of a pharmaceutical is estimated to be excreted in a biologically active form, resulting in pharmaceuticals and their metabolites excreted by humans and discharged into sewers and further into water bodies constituting the main environmental burden of pharmaceuticals. Medicines incorrectly disposed of in sewers and mixed waste by households also constitute environmental emissions. However, precise figures reflecting the contribution from the general public to environmental emissions were not stated in the report as the contributions vary regionally. According to the report, in Europe and North America it is estimated that only $2 \%$ of the total emissions of pharmaceuticals to the environment is a direct consequence of pharmaceuticals' manufacture. The rest of the emissions result from the use and inappropriate disposal of pharmaceuticals.

Globally, continuing environmental and biodiversity losses are resulting in different political decisions and further impacts on people's everyday lives. At the same time, environmentally aware consumers are demanding responsible and environmentally friendly products, and consequently place great emphasis on environmental sustainability when considering purchases [7]. The pharmaceutical sector and researchers have contributed to meeting this demand and to improving public perception of the pharmaceutical industry by giving greater consideration to environmental issues and sustainability [8].

It is crucial that the ordinary use of medicines is recognized as the main source of pharmaceutical emissions into the environment, and that it is noted and specified as one of the main challenges to the environmental sustainability of the pharmaceutical sector. Although the general public has been identified as one of the key stakeholders in communications about the environmental impact of pharmaceuticals, existing research on the subject is scarce. Currently there is a lack of information on how the general public perceives the environmental effects of pharmaceuticals, how much people know about them, and what is the level of concern and worry on the issue. The population perspective on pharmaceuticals and the environment has been studied more in terms of medicine disposal practices and attitudes [9-12], and only a few studies have focused on the risk perception and level of knowledge among the general public [13-15].

According to Dohle et al. [14], among the general U.S. population $(n=640)$, older adults and women were more aware of the environmental consequences of pharmaceuticals than other respondents. The respondents also considered pharmaceuticals used in agriculture to have a greater environmental impact than human medicines. In the study, the severity of the illness concerned affected willingness to substitute a pharmaceutical for a product with a less negative environmental impact. For severe health risks, the willingness to substitute a pharmaceutical for a more environmentally friendly product was lower. In the study by Alajärvi et al. [13], among the Finnish population $(n=2104)$, women were more worried about the environmental impact of pharmaceuticals and considered pharmaceuticals to pose a risk to the environment more often than men. In the same study, women and older people were more often aware of the proper method of disposal of expired or unwanted medicines than other respondents. In the study among the German population $(n=2026)$ by Götz et al. [15], respondents considered wastewaters from the pharmaceutical industry to be the most significant source of pharmaceutical residues in the waterways, and pharmaceuticals excreted in urine to have the least significant role as a perceived environmental source of pharmaceuticals. The perceived role of the pharmaceutical industry as an environmental source of pharmaceuticals was rather unclear in the study by Alajärvi et al. [13], in which $37 \%$ of respondents considered wastewater effluents from the pharmaceutical industry to be a major source of pharmaceutical emissions to the environment, while $27 \%$ of respondents could not provide an answer. However, 
$79 \%$ of respondents agreed that pharmaceuticals end up in the environment mainly as a consequence of humans using medicines.

Perceived environmental risks may also be a rationale for human health worries, as has been shown by research based on the Modern Health Worries Scale introduced by Petrie et al. [16]. As a component of environmental pollution, the environmental effects of pharmaceuticals could be included under the concept of modern health worries. If the risks of pharmaceuticals in the environment are acknowledged, such modern health worries might prompt people to be more environmentally aware in their use of medicines. The impact of knowledge, attitudes, feelings, and personal values on pro-environmental behavior is a complex system that has been studied and modelled since the late 1970s [17]. Now in the 2000s, several internal factors (knowledge, feelings, values, attitudes), external factors (infrastructure, political, social, cultural, economic situation, etc.), and factors that discourage pro-environmental behavior have been identified for inclusion in the model. A meta-analysis by Whitburn et al. [18] found a positive correlation between people's connection with nature and pro-environmental behavior, indicating a possibility that strengthening the connection with nature could motivate people to engage in pro-environmental behavior, making it a key factor in the complex system of pro-environmental behavior.

The aim of this study was to determine the awareness, perceptions, attitudes, and opinions towards pharmaceuticals-related environmental issues among the Finnish population. The specific research questions addressed were:

1. What is the level of awareness of pharmaceutical residues in Finnish waterways among the Finnish population, and what are the perceptions regarding the importance of different sources of emissions of pharmaceuticals into Finnish waterways?

2. How are familiarity, risk perception, and concern related to the environmental impact of pharmaceuticals among the Finnish population?

3. What are the attitudes and opinions on issues concerning environmentally friendly ways of using medicines and on a more environmentally sustainable pharmaceutical sector among the Finnish population?

4. How do age, gender, education level, health status, recent use of medications, and general environmental attitude of the respondent affect the questions posed above?

The study was conducted as part of the multidisciplinary SUDDEN (Sustainable Drug Discovery and Development with End-of-Life Yield) research project that aims at reducing the environmental hazards related to the life cycle of pharmaceuticals and supporting sustainable growth in the pharmaceutical sector [19].

This paper is structured as follows. Section 2 presents the materials and methods, i.e., study context, data collection, questionnaire design, statistical analysis, and ethical considerations. Section 3 presents the survey results; general environmental attitudes and pharmaceuticals-related environmental awareness, attitudes, and opinions are examined. In Section 4, a discussion of our study results is reported. The conclusions of our study are presented in Section 5.

\section{Materials and Methods}

\subsection{Study Context}

In 2019, Finland had approximately 5.5 million residents, the average age being 44.5 years for women and 41.8 years for men [20]. Everyone residing in Finland is guaranteed adequate healthcare services by the government, and the services are provided by each municipality so that they are equally accessible to all residents [21]. According to a nationally representative health examination survey among the Finnish population coordinated by the National Institute for Health and Welfare, $54.4 \%$ of the respondents reported having a long-term illness or health issue [22]. The figures were $51 \%$ for men and $57.7 \%$ for women.

Total sales of pharmaceuticals on the Finnish market in 2019 were 3460 million euros, of which prescription medicines in outpatient care accounted for 2284 million euros [23]. The 10 biggest-selling pharmaceuticals based on total sales at wholesale prices in Finland 
included chemotherapeutic medicines, antivirals, direct oral anticoagulants, immunoglobulin, and nicotine, which accounted for total sales of 450 million euros. Cardiovascular medications, analgesics, and proton pump inhibitors had the highest consumption rates in Finland as measured by defined daily doses (DDD). In 2019, Finland's pharmaceutical imports were worth 1981 million euros and exports, 666 million euros [24]. Pharmaceuticals are sold only from registered pharmacies in Finland, and in 2019 there were 819 community pharmacies, making a total of one pharmacy for around every 6700 citizens [25]. In addition to distributing medicines, Finnish community pharmacies have traditionally had a major role in giving information on rational and proper use of medicines as well as in collecting and properly disposing of expired and unneeded medicines from the public. According to a survey of medicine disposal practices among Finnish residents in 2019 $(n=2030), 89 \%$ of respondents returned liquid medicines to a pharmacy and $93 \%$ returned solid medicines [26].

Like other Europeans, people in Finland value the environment highly, 95\% of them personally consider protecting the environment to be very or fairly important [27]. The corresponding figure for Europeans as a whole is $94 \%$. According to a survey carried out by Finland's Ministry of the Environment and the Finnish Environment Institute in 2018, $90 \%$ of respondents $(n=1054)$ considered nature to be very important or important to them, and $67 \%$ spent time out in nature on a weekly basis [28]. According to the respondents, the highest perceived threats to nature were littering, climate change, and chemicalization of the environment.

\subsection{Data Collection}

Data were collected via an online survey among the Finnish adult population aged 18-79 years in December 2019. The Åland Islands, which constitute an autonomous and monolingual Swedish region of Finland, were excluded. Data collection was performed by an experienced market research company using its pre-recruited online research panel. The panel consists of approximately 40,000 members living in all regions of mainland Finland and voluntarily receiving invitations to participate in different surveys. Survey invitations were sent in six rounds by e-mail. The first round of invitations was sent on 3 December and the last on 19 December 2019. The invitation process was based on the expected and realtime, monitored response rates of different demographic groups. This enabled monitoring the demographic features of the sample and targeting new invitations at those demographic groups that were otherwise underrepresented in the sample. The first round of invitations was sent out based on the presumption of expected response rate, and for invitations to panelists from certain regions of Finland, gender and age were weighted. Since young people ( $<30$ years old) are known to be more passive in participating in surveys, invitations to this age group were weighted when sending the following invitations to collect a representative sample of the Finnish population. In addition, a total of 5300 invitation reminders were sent specifically to the $<30$ years age group, and many of the panelists in this age group received 2-4 reminders. During the survey, a total of 12,999 invitations were sent to the panelists. Data collection was discontinued after reaching the target of 2000 respondents.

\subsection{Questionnaire Design}

The survey questionnaire included 26 structured and Likert-scale questions. The questions were designed to collect information on environmental values in general, as well as awareness, information received and information needed, opinions/attitudes, and valuations concerning the importance attached to pharmaceutical-related environmental issues. The questionnaire also included a discrete choice experiment section aimed at discovering respondents' attitudes and monetary valuations regarding environmentally friendly pharmaceutical policy. The survey questions were designed based on the literature $[15,27,29,30]$ and the expertise and considerations of the researchers (L.A., J.T., J.M.). As a part of the SUDDEN research project [19], the overall objective of this survey was 
to collect preliminary information about the awareness and perspective of the Finnish population towards ecological sustainability challenges in the pharmaceutical sector, and the questions were included to serve this purpose. Face validity testing was performed by five faculty members with prior expertise in designing and conducting questionnaire surveys. Thereafter, the questionnaire was piloted using convenience sampling of adult respondents $(n=25)$. Minor changes in the questionnaire were made as a result.

This study considered the questions designed to learn about the awareness of traces of pharmaceuticals in Finnish waterways, perceptions of the importance of different pharmaceutical emission sources for Finnish waterways, pharmaceuticals-related environmental attitudes and opinions, and a question including five statements concerning environmental opinions in general $[27,30]$.

Awareness of the presence of pharmaceutical residues in waterways was investigated using the structured question "Were you aware that pharmaceutical residues have been found in Finnish waterways?", with answer options "yes" and "no". A similar question has been used by Kotchen et al. [29] in a study of attitudes towards an environmentally friendly medicines' disposal program among citizens of Southern California. According to their study, respondents who were aware of pharmaceutical residues in treated wastewater and surface waters more frequently used a disposal method that prevents pharmaceutical emissions to the environment.

Respondents' opinions concerning the importance of different pharmaceutical emission sources were measured using the question "How much of an impact do you think the following emissions sources have regarding medicinal agents ending up in Finnish waterways?" with a list of known sources of pharmaceutical emissions: "Hospitals and care institutions (human excretions ending up in sewers and disposal of medicines in drains or in mixed waste)", "Households (disposal of medicines in drains or in mixed waste)", "Wastewaters from the pharmaceutical industry", "Excretions from treated farm animals", and "Pharmaceuticals in human urine". Respondents stated their opinions on each of the emission sources using a four-item, Likert-type scale list for the degree of impact: 1 = major impact, 2 = moderate impact, $3=$ minor impact, and $4=$ no impact. A similar question about emission sources was used by Götz et al. [15] in a study of risk perceptions of the environmental effects of pharmaceuticals by the general population in Germany. The study results indicated knowledge gaps regarding the sources of pharmaceuticals in the environment and a reason to engage with the general public in order to promote a more environmentally friendly pharmaceutical policy.

Familiarity, risk perception, and concern related to the environmental impact of pharmaceuticals; attitudes and opinions on issues concerning environmentally friendly ways of using medicines; and attitudes and opinions on a more environmentally sustainable pharmaceutical sector in Finland were measured using a list of 10 statements. The statements had a five-item, Likert-scale list for the degree of agreement: $1=$ completely agree, 2 = somewhat agree, 3 = somewhat disagree, $4=$ completely disagree, and $5=$ I don't know. Of these statements, two were used earlier by Götz et al. [15]: "Pharmaceutical residues in nature pose a risk to the environment" and "Physicians prescribing a medicinal product should consider the environmental impact of the product where possible". The other statements were designed by the researchers for the objectives of the SUDDEN research project.

Our study used a set of sociodemographic factors as background characteristics. These factors were age, gender, education, health status, recent use of medicines, and area of residence as they have been found to affect the results in previous survey studies of environmental issues related to pharmaceuticals $[13,14,29]$. The market research company provided pre-collected background data on the respondents, of which gender, age, and level of education were used in our study. In addition, the questionnaire included structured questions regarding respondents' possible long-term illnesses and use of prescription and over-the-counter (OTC) medicines during the past week. Moreover, respondents' general environmental attitude was used as a background characteristic as it may reflect the attitudes and opinions towards the environmental impact of pharmaceuticals [14]. 
General environmental attitudes were defined based on statements previously used in the Special Eurobarometer by the European Commission $[27,30]$. These statements have been previously used to study the attitudes of European citizens towards the environment in 28 European Union countries. The statements were: "Protecting the environment is important to me", "I am worried about the health effects of the chemicals in products that I use daily", "I am worried about the environmental effects of the chemicals in products that I use daily", "In terms of environmental protection, the actions of individual people matter in Finland", and "The largest polluters should have the main responsibility for remedying the environmental damage they cause". The respondents answered the statements using a five-item, Likert-scale list for their degree of agreement: $1=$ completely agree, $2=$ somewhat agree, 3 = somewhat disagree, $4=$ completely disagree, and $5=$ I don't know.

\subsection{Statistical Analysis}

Frequencies and cross-tabulations were used to analyze and describe the data concerning the research questions. Differences between characteristics of the study population and the whole Finnish population were analyzed using Pearson's chi-squared test for categorical characteristics (gender, age group, education level, area of residence). To compare our study population with the characteristics of the whole Finnish population, we used the statistical database provided by Statistics Finland [20]. Pearson's chi-squared test was used to analyze differences between the answers of the respondents based on their sociodemographic characteristics (age group, gender, education level), long-term illness, and recent use of medicines. For descriptive statistics, the five-class, Likert-scaled questions about opinions and attitudes concerning pharmaceuticals and the environment were recategorized into three classes: "somewhat agree" and "completely agree" were combined into class "agree", and "somewhat disagree" and "completely disagree" into class "disagree".

Latent class analysis (LCA) was used to compress data to a single categorical variable by identifying latent, unobserved, qualitatively different subgroups of respondents with similarities in response patterns to the five Likert-scaled statements concerning general environmental attitudes. LCA is based on an assumption that latent subgroups, i.e., classes, exist and conditional independence between the statements is received given the identified classification. LCA assigns respondents to classes based on their probability of being in classes given the pattern of answers they have on the statements. LCA was selected because of its superiority as a model-based clustering method and because it is suitable for categorical data. LCAs were estimated using the EM algorithm and maximum likelihood. Respondents with Likert answers "I don't know" to all of the statements were excluded from LCAs $(n=5)$. Models with 1-5 classes were iteratively fitted because the number of classes was not known a priori (Appendix A, Table A1). Akaike's Information Criteria (AIC) and Bayesian Information Criteria (BIC) were used to compare alternative models with smaller values indicating better fit with data. Vuong-Lo-Mendell-Rubin and LowMendel-Rubin likelihood ratio tests with $p$-values less than 0.05 were considered to indicate better fit for an $n$-class model than for an $n$ - 1 class model. Entropy was used to guide the classification accuracy of the model, with higher values indicating better classification. In addition to these metrics, the interpretability of the model was used to guide selection of the final model. The selected model was replicated utilizing the initial value of starting value sets to ensure that the solution was for global maximum, not a local one.

Pearson's chi-squared test was used to analyze the differences in the answers between the latent classes. Furthermore, a multivariate multinomial logistic regression model was used to examine associations between the extracted latent classes and sociodemographic characteristics.

LCAs were fitted using Mplus [31] Version 8. Other statistical analyses were performed using IBM SPSS Version 25.0 (SPSS, Inc., Chicago, IL, USA). A $p$-value less than 0.05 was considered statistically significant. 


\subsection{Ethical Considerations}

The study setting and research process complied with national ethical instructions for research [32]. No ethical approval was required for the study. Participation in the survey was voluntary and responding to the questionnaire was interpreted as informed consent to participate in the study for research purposes.

\section{Results}

\subsection{Study Population and General Environmental Attitudes}

A total of 2030 responses were obtained. The mean (SD) age of the respondents was 50.0 (14.9) years and 53.9\% of the respondents were women (Table 1). All regions of mainland Finland were represented in our survey demographics. Compared to the whole Finnish population, women, respondents aged 35-74 years, respondents from Southern Finland, and respondents with upper secondary education and tertiary education were overrepresented.

Table 1. Study population $(n=2030)$ compared to the whole Finnish population $(n=5,495,408)$.

\begin{tabular}{|c|c|c|c|c|c|}
\hline & \multicolumn{2}{|c|}{ Respondents } & \multicolumn{2}{|c|}{ Finnish Population ${ }^{1}$} & \multirow[t]{2}{*}{$p$-Value ${ }^{2}$} \\
\hline & $n$ & $(\%)$ & $n$ & $(\%)$ & \\
\hline \multicolumn{6}{|c|}{ Gender } \\
\hline Female & 1094 & $(53.9)$ & $2,782,025$ & $(50.6)$ & 0.003 \\
\hline Male & 936 & $(46.1)$ & $2,713,383$ & $(49.4)$ & 0.003 \\
\hline \multicolumn{6}{|c|}{ Age } \\
\hline $0-17$ & $0^{4}$ & $(0.0)$ & $1,043,147$ & $(19.0)$ & \\
\hline $18-34$ & 393 & $(19.4)$ & $1,133,611$ & $(20.6)$ & \\
\hline $35-59$ & 1020 & $(50.2)$ & $1,736,436$ & $(31.6)$ & $<0.001$ \\
\hline $60-74$ & 532 & $(26.2)$ & $1,060,573$ & $(19.3)$ & $<0.001$ \\
\hline $75-79$ & 85 & $(4.2)$ & 210,889 & $(3.8)$ & \\
\hline $80-$ & $0^{4}$ & $(0.0)$ & 310,752 & $(5.7)$ & \\
\hline \multicolumn{6}{|c|}{ Area of residence } \\
\hline Southern Finland & 917 & $(45.2)$ & $2,359,178$ & $(42.9)$ & 0.041 \\
\hline Southwest Finland & 266 & $(13.1)$ & 696,093 & $(12.7)$ & \\
\hline Eastern Finland & 191 & $(9.4)$ & 547,782 & $(10.0)$ & \\
\hline Inland and Western Finland & 457 & $(22.5)$ & $1,230,058$ & $(22.4)$ & \\
\hline Northern Finland & 159 & $(7.8)$ & 485,136 & $(8.8)$ & \\
\hline Lapland & 40 & $(2.0)$ & 177,161 & $(3.2)$ & 0.001 \\
\hline \multicolumn{6}{|c|}{ Education level } \\
\hline Elementary school ${ }^{3}$ & 166 & $(8.2)$ & $1,053,534$ & $(24.0)$ & $<0.001$ \\
\hline Upper secondary education & 1022 & $(50.3)$ & $1,875,301$ & $(42.7)$ & $<0.001$ \\
\hline Tertiary education & 842 & $(41.5)$ & $1,465,863$ & $(33.4)$ & $<0.001$ \\
\hline
\end{tabular}

${ }_{1}^{1}$ Åland Islands excluded, situation 31 December $2019 ;{ }^{2}$ only statistically significant $p$-values are presented; ${ }^{3}$ or education unknown, 18 years and older, situation 31 December $2018 ;{ }^{4}$ age group excluded from the survey.

In terms of general environmental attitudes, $91.2 \%$ of the respondents considered environmental protection to be important to them, $68.9 \%$ were worried about the environmental effects of chemicals in everyday use, and $54.7 \%$ were worried about the health effects of chemicals in everyday products (Appendix A Table A2). Actions by individual people for environmental protection were considered meaningful by $87.4 \%$ of the respondents, and $94.4 \%$ agreed that the biggest polluters should be mainly responsible for remedying the environmental damage they cause. 
Three latent classes, "pro-environmental", "environmentally inclined", and "moderates", were identified based on the model diagnostics used (Appendix A Table A1). For the chosen LCA model, entropy 0.785 was close to the suggested minimum level of 0.8 , and minimum average latent class posterior probability was 0.874 . The classes differed in relation to general opinions and attitudes towards the environment (Appendix A Table A2). The largest number of respondents (39.6\%) were in the "pro-environmental" class as they gave the keenest pro-environmental responses. The second largest class, the "environmentally inclined", included $31.7 \%$ of the study population, representing intermediate pro-environmental responses, and $28.7 \%$ of the respondents belonged to the class "moderates" representing the least pro-environmental responses.

Of the respondents in the "moderates" class, $61.5 \%$ were men while $67.7 \%$ of respondents in the "pro-environmental" class were women $(p<0.001)$ (Appendix A Table A2). The mean age of the respondents in the "pro-environmental" class was 50.8 (15.6) years, in the "environmentally inclined" class 51.6 (14.8) years, and in the "moderates" class 47.0 (13.7) years. The highest level of education was most frequently upper secondary education in all three classes. Tertiary education was most common in the "pro-environmental" class, with elementary school most commonly being the highest level of education in the "environmentally inclined" class $(p<0.001)$. Having a long-term illness was most common in the "environmentally inclined" class and least common in the "moderates" class $(p=0.04)$. Based on the multinomial logistic regression model, females were less likely to belong to the "environmentally inclined" or "moderates" classes than to the "pro-environmental" class (Table 2). Older age was associated with lower odds of belonging to the "moderates" class than to the "pro-environmental" class. Furthermore, those with higher than elementary education were less likely to belong to the "environmentally inclined" class than to the "pro-environmental" class.

Table 2. Adjusted, multivariable odds ratios ( $95 \%$ confidence intervals) for the association of characteristics with estimated classes. Pro-environmental class $(n=801)$ as a reference group.

\begin{tabular}{ccc}
\hline & $\begin{array}{c}\text { Environmentally } \\
\text { Inclined }(\boldsymbol{n}=\mathbf{6 4 2})\end{array}$ & Moderates $(\boldsymbol{n}=\mathbf{5 8 2})$ \\
\hline OR $(95 \% \mathrm{CI})$ & OR $(95 \% \mathrm{CI})$ \\
\hline Female & $0.51(0.41-0.63)$ & $0.27(0.21-0.34)$ \\
\hline Age & $1.00(0.99-1.00)$ & $0.97(0.97-0.98)$ \\
\hline Education & 1 (reference) & 1 (reference) \\
\hline Elementary school & $0.63(0.42-0.93)$ & $0.80(0.41-1.27)$ \\
\hline Upper secondary education & $0.42(0.28-0.64)$ & $0.66(0.41-1.05)$ \\
\hline
\end{tabular}

\subsection{Pharmaceuticals-Related Environmental Considerations}

3.2.1. Awareness of Pharmaceutical Residues in Finnish Waterways and Perceptions Regarding the Relative Importance of Different Sources of Pharmaceutical Emissions

Of the respondents, $89.5 \%$ were aware that traces of pharmaceuticals have been measured in Finnish waterways (Appendix A Table A3). Stated awareness was more common in the oldest age group (75-79 years) than in the youngest age group (18-34 years) $(p<0.001)$ and among those respondents with the highest level of education compared to the respondents with the lowest level of education $(p<0.001)$. Respondents with recent use of prescription medicines were more frequently aware than those without recent use of prescription medicines ( $p=0.024)$ (Appendix A Table A4). The "pro-environmental" class was most frequently aware of the issue, and the "moderates", least frequently aware $(p<0.001)$ (Appendix A Table A2).

Wastewaters from the pharmaceutical industry were most frequently $(52.6 \%)$ considered to have a major impact as an environmental source of pharmaceutical emissions in 
Finland. However, pharmaceuticals excreted in human urine were least frequently (31.9\%) considered to have a major impact (Figure 1). Of the respondents, women $(p<0.001)$ and the $75-79$ years age group $(p=0.001)$ most frequently considered the pharmaceutical industry to have a major impact, whereas respondents with the highest education level most frequently considered the impact to be moderate or minor $(p<0.001)$ (Appendix A Table A3). Respondents who had recently used prescription medicines considered wastewaters from the pharmaceutical industry to have a major impact more frequently than respondents with no recent use of prescription medicines $(p=0.006)$ (Appendix A Table A4). Overall, respondents in the "pro-environmental" class most frequently considered the suggested source to have a major impact than those in the other two classes (Figure 1). Correspondingly, those who least considered these sources to have a major impact on pharmaceutical residues ending up in Finnish waterways were in the "moderates" class.

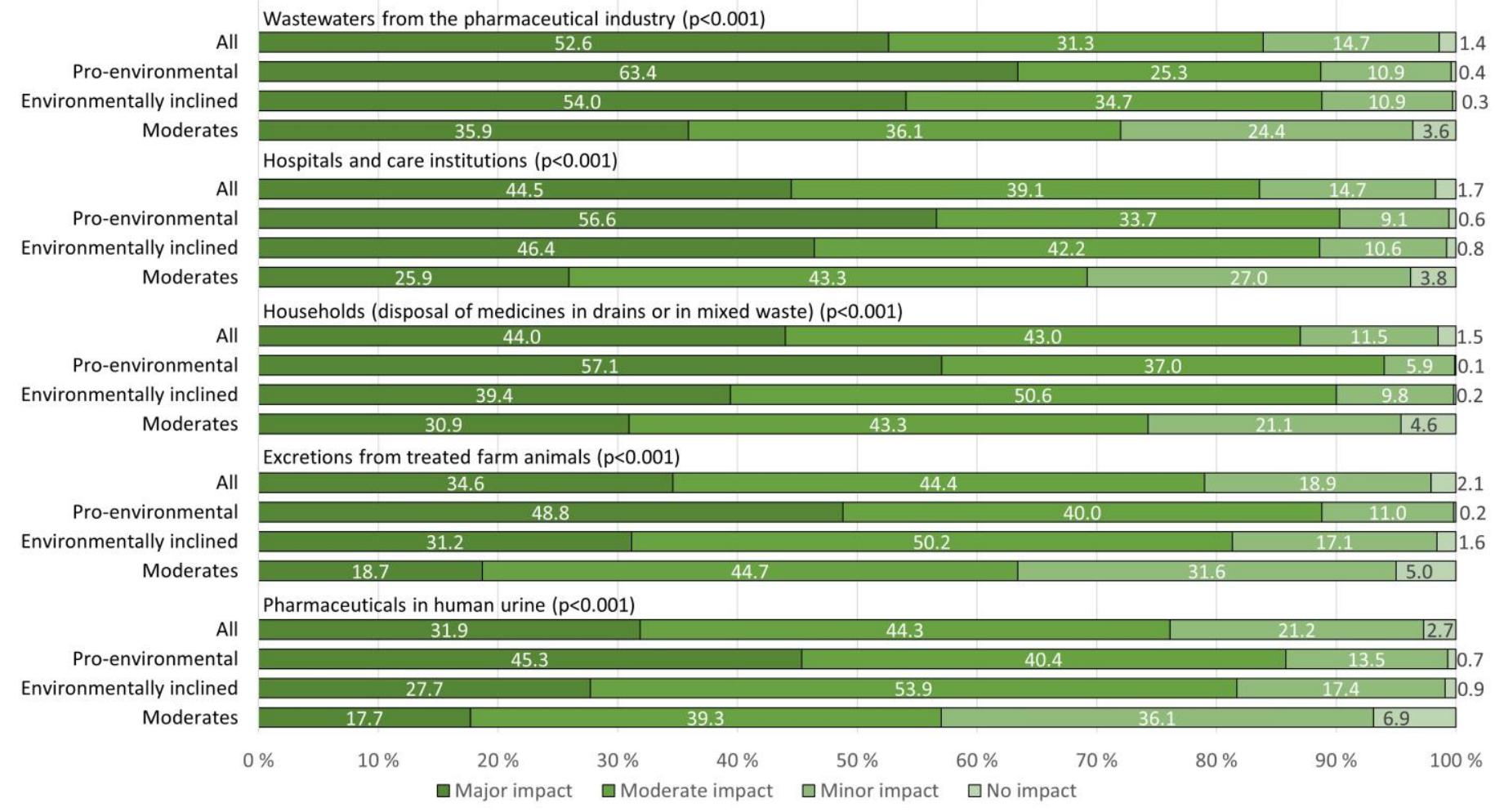

Figure 1. Presumed impact of different emission sources on pharmaceutical residues ending up in Finnish waterways as perceived by the Finnish population $(n=2030)$ and the identified latent classes.

\subsubsection{Opinions and Attitudes Concerning Pharmaceuticals and the Environment}

Familiarity, risk perception, and concern related to the environmental impacts of pharmaceuticals were studied using four statements (Figure 2). The environmental impact of pharmaceuticals was regarded as new and unfamiliar by $26.2 \%$ of the respondents; $89.4 \%$ agreed that pharmaceutical residues pose an environmental risk; $79.7 \%$ were worried about the potential environmental effects of pharmaceuticals; $76.1 \%$ were worried about the human health effects of pharmaceutical residues. 
The environmental impact of pharmaceuticals is a new and unfamiliar thing to me $(p<0.001)$

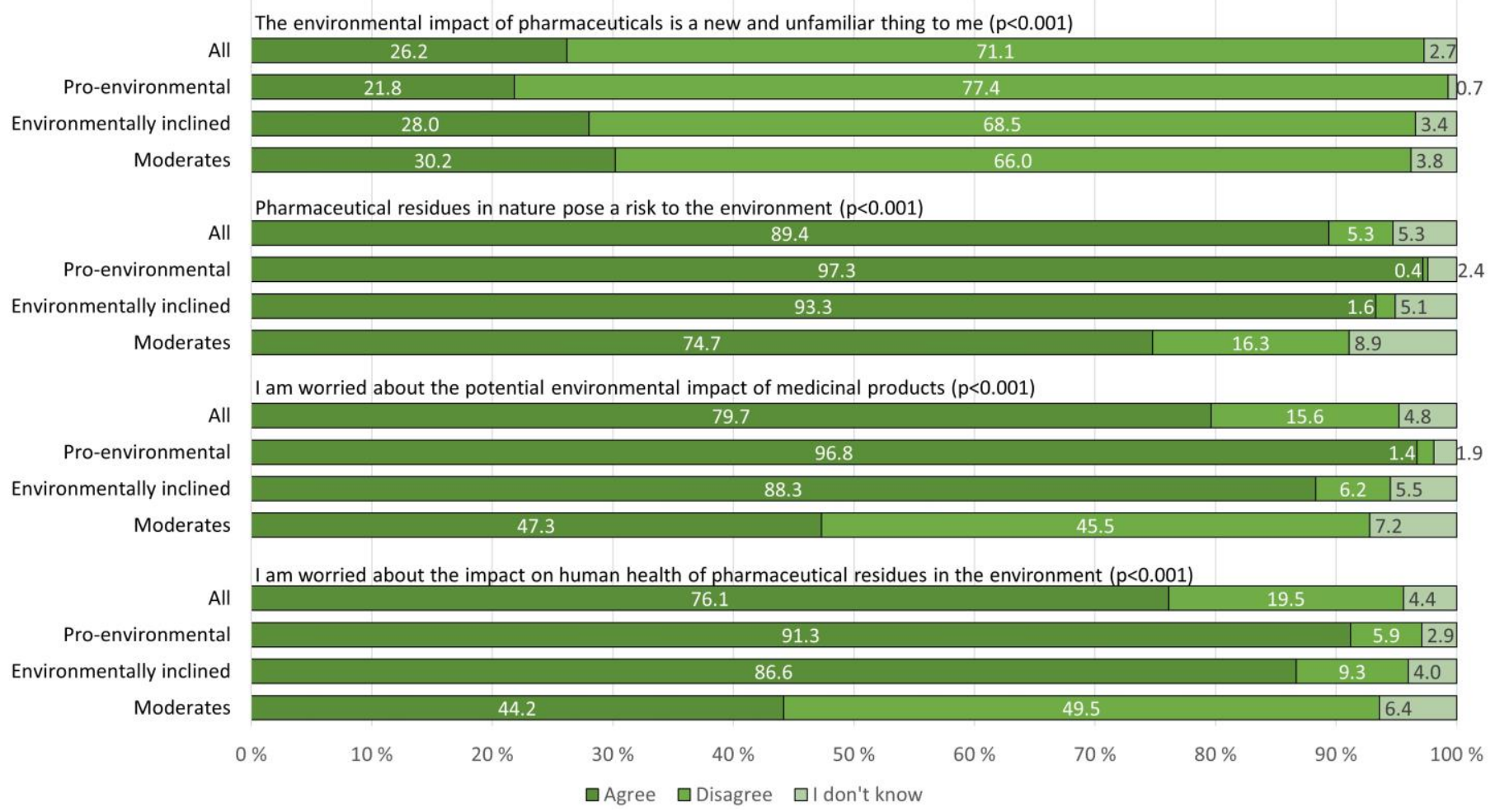

Figure 2. Familiarity, risk perception, and concern related to the environmental impact of pharmaceuticals among the Finnish population $(n=2030)$ and the identified latent classes.

The youngest age group (18-34 years) and those with the lowest level of education most frequently considered the environmental impact of pharmaceuticals to be new and unfamiliar $(p<0.001)$ (Appendix A Table A5). Women, the oldest age group (75-79 years), and respondents with the highest level of education most frequently agreed that pharmaceuticals pose an environmental risk $(p<0.001)$. Worry about environmental and human health effects was more common among women $(p<0.001)$ and the 60-74 and 75-79 years age groups than among younger respondents $(p<0.001)$. Respondents with long-term illnesses were more often worried about the human health effects of pharmaceutical residues in the environment than respondents without long-term illnesses $(p=0.033)$ (Appendix A Table A6).

Of the latent classes, the "moderates" most frequently considered the environmental impact of pharmaceuticals to be new and unfamiliar $(p<0.001)$ (Figure 2). The "moderates" disagreed most frequently that pharmaceutical residues in nature pose an environmental risk, and were least commonly worried about the impact on human health or the environment of pharmaceutical residues in the environment $(p<0.001)$.

The opinions of the respondents on practical issues concerning environmentally friendly ways of using medicines were measured using three statements (Figure 3). Of the respondents, $59.2 \%$ agreed that the environmental impact of a pharmaceutical should be considered when prescribing a medicine, $78.7 \%$ agreed that the package leaflet explains how to dispose of the medicine, and $86.3 \%$ of them considered it important that the packaging materials used for medicines are recyclable. 


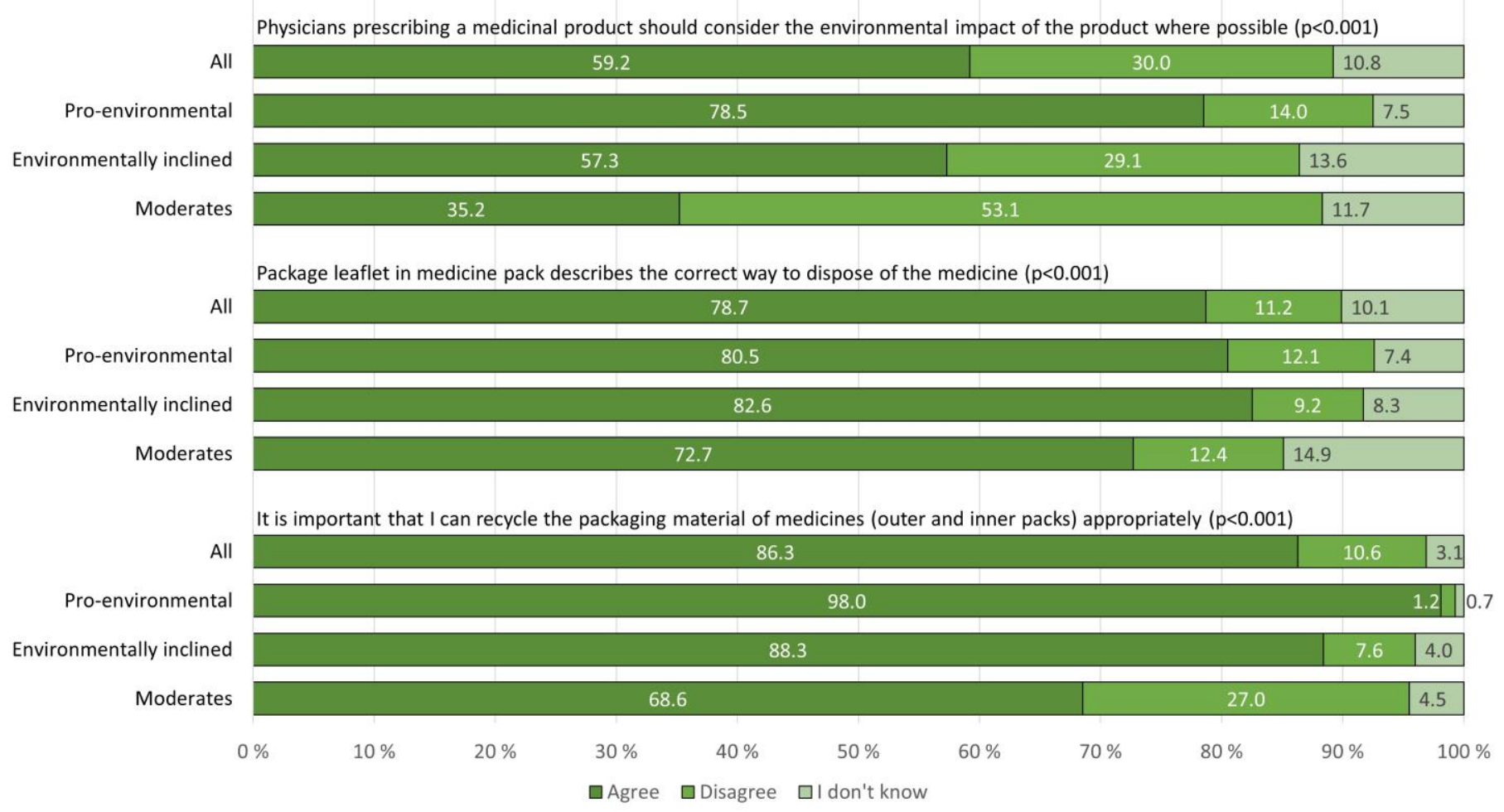

Figure 3. Opinions on practical issues concerning environmentally friendly ways of using medicines among the Finnish population $(n=2030)$ and the identified latent classes.

Women and the oldest age group (75-79 years) most frequently agreed with the statement about environmental considerations when prescribing a medicine $(p<0.001)$ (Appendix A Table A5). The oldest age group (75-79 years) most frequently agreed with the statement about the package leaflet describing the proper way to dispose of the medicine $(p<0.001)$. Women and respondents aged 60 years and older more frequently agreed with the statement about the importance of recyclable packaging materials than men and younger respondents $(p<0.001)$.

Of the latent classes, the "pro-environmental" class most frequently agreed with the statement about environmental considerations when prescribing a medicine $(p<0.001)$, and most frequently with the statement about the importance of recyclable packaging materials $(p<0.001)$ (Figure 3$)$. The "environmentally inclined" most frequently agreed with the statement concerning the package leaflet describing the proper way to dispose of the medicine $(p<0.001)$.

Attitudes towards the roles of stakeholders and their efforts in ensuring an environmentally sustainable pharmaceutical sector in Finland were examined using three statements (Figure 4). Of the respondents, $82.4 \%$ considered it important that they can trust pharmaceutical companies to act in an environmentally sustainable way. Of the respondents, $27.6 \%$ agreed that current wastewater treatment prevents pharmaceuticals from ending up in natural waters, and $13.8 \%$ could not provide an opinion. Finland should set an example in reducing the environmental impact of pharmaceuticals according to $75.0 \%$ of the respondents. 


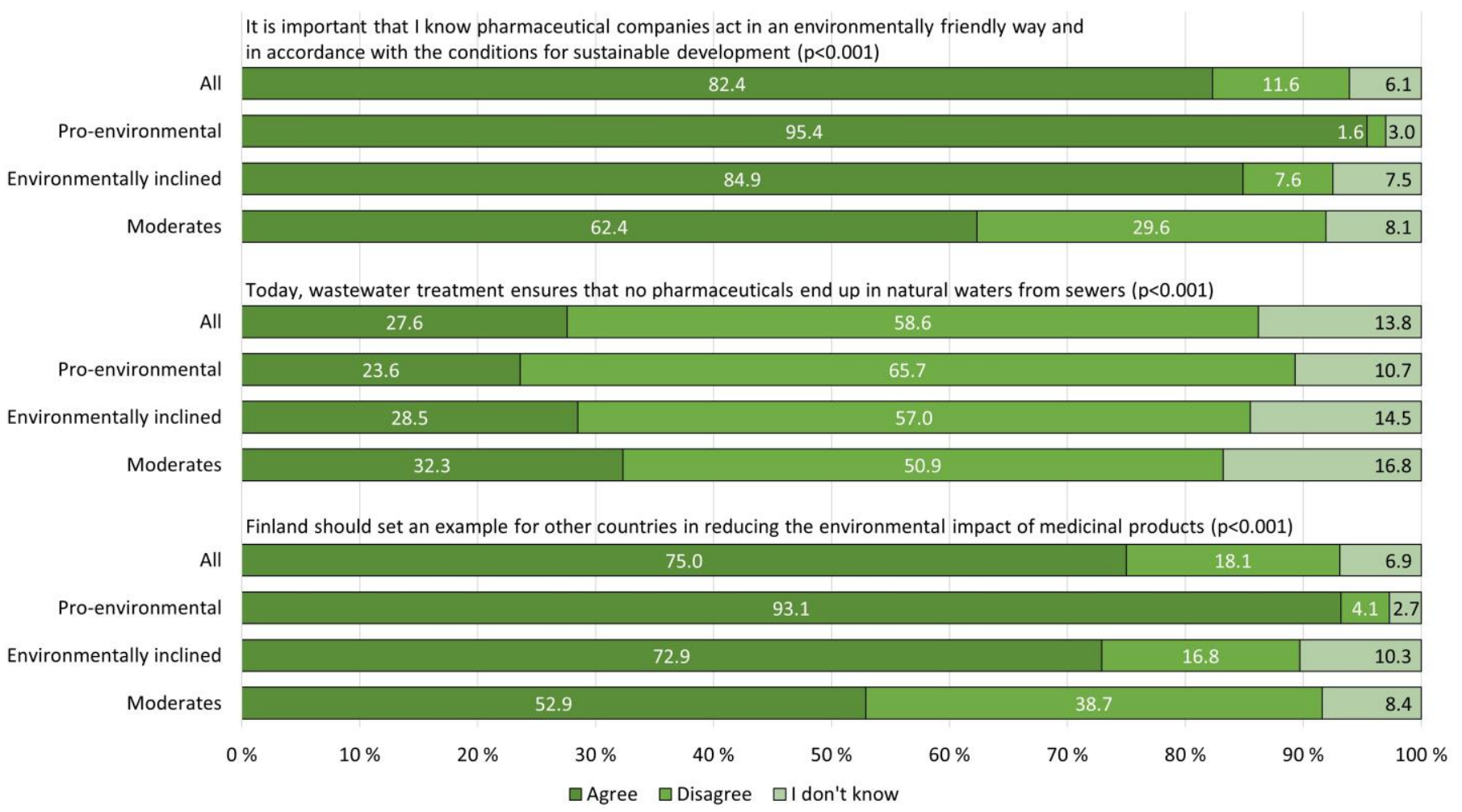

Figure 4. Attitudes towards the roles of stakeholders in ensuring a sustainable pharmaceutical sector in Finland among the Finnish population $(n=2030)$ and the identified latent classes.

Knowing that pharmaceutical companies act in an environmentally sustainable way was most frequently considered important by women and the oldest age groups (60-74 and $75-79$ years) $(p<0.001)$ (Appendix A Table A5). Women were more frequently unable to express their opinion on the capacity of wastewater treatment to remove pharmaceuticals compared to men $(p=0.004)$. Of the different age groups, the oldest age group agreed with this statement most frequently $(p=0.002)$, and respondents with the highest education level least frequently agreed with this than those with lower levels of education $(p<0.001)$. Women and respondents with the highest level of education agreed with the statement that Finland should set an example in reducing the environmental impact of pharmaceuticals more frequently than men and respondents with lower education levels $(p<0.001)$. Of the age groups, the youngest and the oldest age groups agreed with this statement most frequently $(p=0.013)$. Respondents who had recently used OTC medicines more frequently agreed that Finland should set an example in reducing the environmental impact of pharmaceuticals than those without recent use of OTC medicines $(p=0.032)$ (Appendix A Table A6).

Of the latent classes, the "moderates" agreed most frequently that wastewater treatment ensures that no pharmaceuticals end up in natural waters $(p<0.001)$ (Figure 4$)$. The "pro-environmental" most frequently agreed about the importance of knowing that pharmaceutical companies act in an environmentally sustainable way $(p<0.001)$, and that Finland should set an example in reducing the environmental impact of medicines $(p<0.001)$.

\section{Discussion}

According to this research, Finnish people are well aware of the presence of pharmaceuticals in the country's environment. However, the root causes of their release are not familiar to the general public as the pharmaceutical industry is most frequently seen as having a significant environmental impact, while the pharmaceuticals excreted in human urine are least frequently considered to have a significant impact. Generally, worry over 
the environmental or human health effects of pharmaceutical residues was high among the respondents. Despite this, the opinions of the respondents on physicians prescribing more environmentally friendly medicines were clearly divided. The use of recyclable packaging materials for pharmaceuticals was a more preferred way to act environmentally friendly among the respondents. In this study, statistically significant differences in the awareness and perceived importance of different pharmaceutical emission sources into the environment and opinions and attitudes concerning pharmaceuticals-related environmental issues were found in relation to the respondents' gender, age, education level, and environmental attitude. Long-term illnesses or recent use of medicines was statistically significantly associated in the responses in only in a few respects.

4.1. Awareness of Pharmaceutical Residues in Finnish Waterways and Perceptions Regarding the Relative Importance of Different Sources of Pharmaceutical Emissions

The respondents were widely aware of the presence of pharmaceutical residues in Finnish waterways. In this study, higher age, higher level of education, and recent use of prescription medicines were associated with the stated awareness. Of the latent classes, respondents in the class "pro-environmental" were most frequently aware of the issue. Despite generally being well aware of the issue, the root causes and their significance remain unclear among the population. Finnish people seem to overestimate the role of the pharmaceutical industry as a source of pharmaceutical pollution, and the roles of the other pollution sources considered in this study are not well known either. The role of pharmaceuticals excreted by humans was underestimated, even by the class "proenvironmental", which has the largest proportion of highly educated respondents and which is most frequently aware of the presence of pharmaceutical residues in Finnish waterways. Even though most of the respondents were to some extent familiar with the environmental impact of pharmaceuticals, and though most saw pharmaceutical residues as a risk to the environment, the results indicate a lack of knowledge about the causes of the environmental effects of pharmaceuticals. Moreover, some previous studies have shown that the general public's knowledge and beliefs regarding the roles of different sources of pharmaceutical emissions are in contrast with the current scientific consensus $[13,15]$. The studies indicate that the role of the pharmaceutical industry is largely overestimated or unknown, and our current results are in line with these findings of the public perspective. An important topic for future research is to identify the specific information needs, interests, and preferred information channels of the general public regarding the environmental aspect of pharmaceuticals.

\subsection{Opinions and Attitudes Concerning Pharmaceuticals and the Environment}

Women, older respondents, and those with a higher level of education most frequently agreed that pharmaceuticals pose a risk to the environment; women and older respondents also most frequently agreed that they are worried about the environmental or health impact of pharmaceuticals in the environment. These results are in line with earlier results, as women and older people have been found to be more aware of, and worried about, the environmental impact of pharmaceuticals [13,14]. Even though the role of pharmaceuticals as environmental pollutants raises concerns, the respondents were not particularly eager to take environmental issues into account when visiting a physician. This may be because people's own role as the main source of pharmaceutical residues is unrecognized. Other factors could be that the idea of an environmentally friendly pharmaceutical policy is novel and, currently, few opportunities for patients exist to take environmental issues into consideration as users of medicines. We may not fully understand what considering environmental issues in these situations would mean in practice; no environmental classification system for pharmaceuticals has yet been introduced in Finland. However, such a classification system has been used by pharmacists, physicians, and the general public in Sweden since 2005, and different ways of introducing the system in Finland have been discussed [33]. In addition, we cannot ignore that people often consider treating health issues with medications as necessary, which can affect their environmental 
risk perception regarding pharmaceuticals. The benefits that the possible hazard offer to society are known to affect the judgment of perceived risk by the general public [34].

Users of medicines need appropriate information about ways to act in a more environment-friendly manner, without compromising matters such as treatment adherence. More than $65 \%$ of our respondents reported having a long-term illness or health problem diagnosed by a physician. The effect of long-term illness would be an obvious factor to influence the views and opinions of the respondents and thus the results of this study. However, except for one of the statements, no statistically significant differences among the responses of the respondents with or without a long-term illness emerged.

People in Finland are familiar with the proper recycling of different packaging materials, and, based on our study findings, this also applies to pharmaceutical packaging materials. In view of the many forms of pharmaceuticals, including tablets and capsules, the inner blister packaging usually contains aluminum and polyvinyl chloride. Blisters form the bulk of the medical packaging waste that currently ends up in mixed waste due to the lack of an effective process for aluminum recycling, even though aluminum can be recycled using only half of the energy required for primary aluminum production [35]. Our results demonstrate that the general public needs sustainability improvements of this kind in the pharmaceutical sector. Additionally, according to our study, the public is keen for the overall operations of pharmaceutical companies to be made more environmentally sustainable and for Finland to be a nation that works to minimize the environmental harm caused by pharmaceutical residues.

As demonstrated in this study, older age, female gender, and higher level of education are associated with a more pro-environmental attitude. This implies that a general environmental attitude might be one key factor determining how people perceive and consider pharmaceuticals-related environmental issues.

Overall, our study results indicate a high willingness of Finns to adopt environmentally friendly pharmaceutical policy measures. However, in order to achieve this, successful communication on both the causes of the environmental problem and the individuals' possibilities for operating in an environmentally friendly manner are required. Such communication would encourage people to switch to more environmentally friendly pharmaceuticals when possible. Moreover, this successful communication would improve people's perceptions of the roles of the pharmaceutical industry and the users of medicines as environmental sources of pharmaceuticals in Finland. In addition to informing people, the environmental aspect of pharmaceuticals should be considered to be included in the training of health care professionals. This would also facilitate the effective implementation of an environmental classification system of pharmaceuticals in Finland.

\subsection{Strengths and Limitations of the Study}

This research helps to offset the scarcity of existing studies of people's perspective on the environmental effects of pharmaceuticals, giving practical insights for developing a more environmentally friendly pharmaceutical policy. From the perspective of the Finnish population, this study demonstrates the need for a more environmentally sustainable pharmaceutical sector. A total of 2030 respondents in a small country of 5.5 million residents can be considered to form a comprehensive sample; the demographics of the respondents covered adult respondents aged 18 to 79 years from all areas of mainland Finland and all education levels. This study also reviewed the results for a variety of background characteristics including the basic demographic variables, in addition to information about the respondents' environmental attitude, health status, and use of medicines. To our knowledge, there are no previous studies using such an inclusive set of background characteristics to determine their association with awareness and views towards pharmaceuticals-related environmental issues and an environmentally sustainable pharmaceutical sector. General environmental attitude is a widely researched topic, but it has not so far been used in the context of the population perspective on pharmaceuticals and environmental sustainability. This study used LCA in the case of general environmental attitudes of the respondents. 
LCA enables information about several independent background characteristics to be incorporated into one characteristic. This avoided the need to perform several regression analyses when interpreting the effects of the characteristics on the responses, further simplifying the presentation of the results.

The respondents were recruited from the online panel of a market research company. Calculating the response rate of the survey in the usual way for sample surveys is not informative, as respondents are pre-recruited to receive research invitations regardless of the topic, and their response rates differ from the rest of the general population. In online panel surveys it is possible to assess the representativeness of the demographics of the study population compared to the original population of interest. Our sample is not fully representative of the entire Finnish adult population. As in many other questionnaire surveys in Finland, women, elderly people, and highly educated people were overrepresented, while in electronic surveys the overrepresentation of university graduates is typical [36-38]. In addition, people aged 80 and over, who represent approximately $6 \%$ of the Finnish population [20], were excluded from the data collection. Accordingly, the possible effects of these factors should be considered when interpreting and generalizing the results of this study to the entire Finnish population.

The questions used in this article were not validated, but some of them had been used earlier to study the public's views on environmental issues $[15,27,29,30]$. In addition, the face validity of the questionnaire was verified by persons familiar with conducting surveys, and the questionnaire was piloted before the survey, thus improving the validity of the questions. Additionally, some of the questions of our survey were previously used by the European Commission in Eurobarometers, designed to study public opinion for policy development purposes [39]. This may be considered a limitation in scientific research of attitudes and opinions among the general public since, for example, several methodological concerns about the objectivity of the questions and statements of Eurobarometers in general have been discussed [40]. However, despite the possible methodological limitations of Eurobarometers, they provide an opportunity to generalize and compare the opinions of citizens across the EU.

As there is a lack of studies of population perspective towards pharmaceuticals-related environmental issues and environmentally friendly pharmaceutical policy, this study is rather exploratory with no a priori defined theoretical framework. However, a comparison of this research topic with theories emerging from the context of other consumer products or services may be irrelevant as pharmaceuticals are usually essential in the treatment of illnesses. In addition, as discussed in this study, only a few means currently exist for medicine users to act environmentally friendly, and the concept of environmentally friendly pharmaceutical policy is unprecedented to the Finnish public.

\section{Conclusions}

In this study we showed that the environmental friendliness of the Finnish population encompasses issues concerning pharmaceuticals and the environment. Despite the high level of awareness about pharmaceutical residues in Finnish waterways and worry regarding their environmental impact, understanding of the environmental significance of different pharmaceutical emission sources is insufficient. As a matter of fact, the most significant source of pharmaceutical emissions - the ordinary use of medicines and their release into the environment through sewage treatment plants - is perceived as the least significant source of emissions, while emissions from the pharmaceutical industry are perceived as the most significant source. Currently, Finns prefer recycling the packaging materials used for pharmaceuticals over opting for a more environmentally friendly pharmaceutical when visiting a physician as the means to mitigate the environmental impact of pharmaceuticals. The highly educated and elderly respondents of our study were aware of pharmaceutical residues in the environment more commonly than younger and less educated respondents. Higher age and education are also associated with greater concern about the environmental effects of pharmaceuticals. Therefore, advising young people and people with lower edu- 
cation levels about the environmental impact of medicines is particularly important. These results indicate a need for improved communications related to pharmaceuticals-related environmental issues and the significance of different pharmaceutical emission sources in order to gain public acceptance for a more environmentally friendly pharmaceutical policy, including the option to choose more environmentally friendly pharmaceuticals. In order to develop a successful, environmentally friendly pharmaceutical policy, more research is needed on specific information needs and preferred information channels concerning pharmaceuticals-related environmental issues.

Author Contributions: Conceptualization, L.A., J.T. and J.M.; formal analysis, L.A., P.L. and J.T.; funding acquisition, J.M.; investigation, L.A., J.T., P.L. and J.M.; methodology, L.A., J.T., P.L. and J.M.; project administration, J.M.; supervision, J.T. and J.M.; visualization, L.A., P.L., J.T. and J.M.; writing—original draft, L.A.; writing—review and editing, L.A., J.T., P.L. and J.M. All authors have read and agreed to the published version of the manuscript.

Funding: This study was carried out as a part of the SUDDEN (Sustainable Drug Discovery and Development with End-of-Life Yield) project funded by the Strategic Research Council at the Academy of Finland, grant numbers 320210 and 320220.

Institutional Review Board Statement: Ethical review and approval were waived for this study, due to the full compliance of the study with national ethical instructions. According to the guidelines prepared by the National Advisory Board on Research Ethics (TENK), an ethical review is not required for this type of human sciences research in Finland.

Informed Consent Statement: Informed consent was obtained from all subjects involved in the study.

Data Availability Statement: The data presented in this study are available on request from the corresponding author. The data are not publicly available due to ongoing data publication process.

Conflicts of Interest: J.M. is a founding partner of ESiOR Oy and a board member of Siltana Oy. These companies were not involved in conducting this study. The authors report no other conflicts of interest in this work.

\section{Appendix A}

Table A1. Estimation results of latent class analysis models with 1-5 classes.

\begin{tabular}{|c|c|c|c|c|c|c|c|c|c|c|c|c|}
\hline $\begin{array}{l}\text { No. of } \\
\text { Classes }\end{array}$ & $\begin{array}{c}\text { Log- } \\
\text { Likelihood }\end{array}$ & $\begin{array}{c}\text { No. of } \\
\text { Parameters }\end{array}$ & AIC & BIC & Entropy & $\begin{array}{l}\text { VLMR-LRT } \\
p \text {-Value }\end{array}$ & $\begin{array}{l}\text { LMR- } \\
\text { LRT } \\
p \text {-Value }\end{array}$ & & \multicolumn{4}{|c|}{ Class Proportions } \\
\hline 1 & $-10,376.4$ & 15 & $20,782.825$ & $20,867.025$ & NA & NA & NA & 100.0 & & & & \\
\hline 2 & -9447.492 & 31 & $18,956.984$ & $19,130.997$ & 0.752 & $<0.001$ & $<0.001$ & 53.4 & 46.6 & & & \\
\hline 3 & -9139.575 & 47 & $18,373.150$ & $18,636.976$ & 0.785 & $<0.001$ & $<0.001$ & 39.6 & 31.7 & 28.7 & & \\
\hline 4 & -8937.175 & 63 & $18,000.350$ & $18,353.990$ & 0.808 & 0.3397 & 0.3417 & 39.4 & 30.0 & 23.9 & 6.7 & \\
\hline 5 & -8791.756 & 79 & $17,741.512$ & $18,184.965$ & 0.812 & 0.7691 & 0.7692 & 27.6 & 23.7 & 23.1 & 16.4 & 9.1 \\
\hline
\end{tabular}

Abbreviations: AIC, Akaike's Information Criteria; BIC, Bayesian Information Criteria; LMR-LRT, Lo-Mendell-Rubin likelihood ratio test; NA, not available; VLMR-LRT, Vuong-Lo-Mendell-Rubin likelihood ratio test.

Table A2. Comparison among latent classes and their demographics, long-term illnesses, medicine use, opinions, and attitudes to general environmental issues, and awareness of the presence of pharmaceuticals in Finnish waterways.

\begin{tabular}{|c|c|c|c|c|c|c|}
\hline & & \multicolumn{2}{|l|}{ All } & \multicolumn{2}{|l|}{ Latent Classes } & \multirow[b]{2}{*}{$p$-Value } \\
\hline & & $n(\%)$ & $\begin{array}{c}\text { Pro- } \\
\text { Environmental, } \\
n(\%)\end{array}$ & $\begin{array}{l}\text { Environmentally } \\
\text { Inclined, } n(\%)\end{array}$ & $\begin{array}{c}\text { Moderates, } \\
n(\%)\end{array}$ & \\
\hline Total & & $2030(100.0)$ & $801(39.6)$ & $642(31.7)$ & $582(28.7)$ & \\
\hline Gender & Female & $1094(53.9)$ & $542(67.7)$ & 327 (50.9) & $224(38.5)$ & $<0.001$ \\
\hline
\end{tabular}


Table A2. Cont.

\begin{tabular}{|c|c|c|c|c|c|c|}
\hline & & \multicolumn{2}{|l|}{ All } & \multicolumn{2}{|l|}{ Latent Classes } & \multirow[b]{2}{*}{$p$-Value } \\
\hline & & $n(\%)$ & $\begin{array}{c}\text { Pro- } \\
\text { Environmental, } \\
n(\%)\end{array}$ & $\begin{array}{l}\text { Environmentally } \\
\text { Inclined, } n(\%)\end{array}$ & $\begin{array}{c}\text { Moderates, } \\
n(\%)\end{array}$ & \\
\hline \multirow{4}{*}{ Age } & $18-34$ & $393(19.4)$ & $158(19.7)$ & $106(16.5)$ & $128(22.0)$ & \multirow{4}{*}{$<0.001$} \\
\hline & $35-59$ & $1020(50.2)$ & $363(45.3)$ & $312(48.6)$ & $343(58.9)$ & \\
\hline & $60-74$ & $532(26.2)$ & $236(29.5)$ & $201(31.3)$ & $93(16.0)$ & \\
\hline & $75-79$ & $85(4.2)$ & $44(5.5)$ & $23(3.6)$ & $18(3.1)$ & \\
\hline \multirow{3}{*}{ Education level } & $\begin{array}{l}\text { Elementary } \\
\text { school }\end{array}$ & $166(8.2)$ & $48(6.0)$ & $72(11.2)$ & $44(7.6)$ & \multirow{3}{*}{$<0.001$} \\
\hline & $\begin{array}{c}\text { Upper } \\
\text { secondary } \\
\text { education }\end{array}$ & $1022(50.3)$ & $381(47.6)$ & 345 (53.7) & 295 (50.7) & \\
\hline & $\begin{array}{c}\text { Tertiary } \\
\text { education }\end{array}$ & $842(41.5)$ & $372(46.4)$ & $225(35.0)$ & $243(41.8)$ & \\
\hline Long-term illness & Yes & $1326(65.3)$ & $521(65.6)$ & $443(70.5)$ & $361(64.0)$ & 0.04 \\
\hline $\begin{array}{l}\text { Use of prescription } \\
\text { medicines during the } \\
\text { last week }\end{array}$ & Yes & $1363(67.9)$ & 549 (68.7) & $442(69.5)$ & $372(64.9)$ & 0.191 \\
\hline $\begin{array}{l}\text { Use of OTC medicines } \\
\text { during the last week }\end{array}$ & Yes & $860(42.7)$ & $353(44.2)$ & $273(42.9)$ & $234(40.6)$ & 0.405 \\
\hline \multicolumn{2}{|c|}{$\begin{array}{c}\text { Aware of pharmaceutical residues } \\
\text { in natural waters }\end{array}$} & $1817(89.5)$ & $753(94.0)$ & $570(88.8)$ & $491(84.4)$ & $<0.001$ \\
\hline \multicolumn{7}{|c|}{ General environmental opinions and attitudes } \\
\hline \multirow{5}{*}{$\begin{array}{l}\text { Protecting the } \\
\text { environment is } \\
\text { important to me }\end{array}$} & $\begin{array}{l}\text { Completely } \\
\text { agree }\end{array}$ & $1025(50.5)$ & $778(97.1)$ & $130(20.2)$ & $117(20.1)$ & \multirow{5}{*}{$<0.001$} \\
\hline & $\begin{array}{l}\text { Somewhat } \\
\text { agree }\end{array}$ & 839 (41.3) & $18(2.2)$ & $493(76.6)$ & $328(56.4)$ & \\
\hline & $\begin{array}{l}\text { Somewhat } \\
\text { disagree }\end{array}$ & $105(5.2)$ & $0(0.0)$ & $9(1.4)$ & $96(16.5)$ & \\
\hline & $\begin{array}{l}\text { Completely } \\
\text { disagree }\end{array}$ & $38(1.9)$ & $1(0.1)$ & $6(0.9)$ & $33(5.7)$ & \\
\hline & I don't know & $23(1.1)$ & $4(0.4)$ & $6(0.9)$ & $8(1.4)$ & \\
\hline \multirow{5}{*}{$\begin{array}{l}\text { In terms of } \\
\text { environmental } \\
\text { protection, the actions } \\
\text { of individual people } \\
\text { matter in Finland }\end{array}$} & $\begin{array}{l}\text { Completely } \\
\text { agree }\end{array}$ & $943(46.5)$ & $736(91.9)$ & $7(11.8)$ & $131(22.5)$ & \multirow{5}{*}{$<0.001$} \\
\hline & $\begin{array}{l}\text { Somewhat } \\
\text { agree }\end{array}$ & $831(40.9)$ & $60(7.5)$ & $494(76.9)$ & $277(47.6)$ & \\
\hline & $\begin{array}{l}\text { Somewhat } \\
\text { disagree }\end{array}$ & $185(9.1)$ & $1(0.1)$ & $56(8.7)$ & $128(22.0)$ & \\
\hline & $\begin{array}{l}\text { Completely } \\
\text { disagree }\end{array}$ & $55(2.7)$ & $1(0.1)$ & $12(1.9)$ & $42(7.2)$ & \\
\hline & I don't know & $16(0.8)$ & $3(0.4)$ & $4(0.6)$ & $4(0.7)$ & \\
\hline
\end{tabular}


Table A2. Cont.

\begin{tabular}{|c|c|c|c|c|c|c|}
\hline & & \multicolumn{2}{|l|}{ All } & \multicolumn{2}{|l|}{ Latent Classes } & \multirow[b]{2}{*}{$p$-Value } \\
\hline & & $n(\%)$ & $\begin{array}{c}\text { Pro- } \\
\text { Environmental, } \\
n(\%)\end{array}$ & $\begin{array}{l}\text { Environmentally } \\
\text { Inclined, } n(\%)\end{array}$ & $\begin{array}{l}\text { Moderates, } \\
n(\%)\end{array}$ & \\
\hline \multirow{5}{*}{$\begin{array}{l}\text { The biggest polluters } \\
\text { should have the main } \\
\text { responsibility for } \\
\text { remedying the } \\
\text { environmental damage } \\
\text { they cause }\end{array}$} & $\begin{array}{l}\text { Completely } \\
\text { agree }\end{array}$ & $1286(63.3)$ & $603(75.3)$ & $387(60.3)$ & $296(50.9)$ & \multirow{5}{*}{$<0.001$} \\
\hline & $\begin{array}{l}\text { Somewhat } \\
\text { agree }\end{array}$ & $632(31.1)$ & 169 (21.1) & $233(36.3)$ & $230(39.5)$ & \\
\hline & $\begin{array}{l}\text { Somewhat } \\
\text { disagree }\end{array}$ & $61(3.0)$ & $20(2.5)$ & $9(1.4)$ & $32(5.5)$ & \\
\hline & $\begin{array}{l}\text { Completely } \\
\text { disagree }\end{array}$ & $19(0.9)$ & $5(0.6)$ & $0(0.0)$ & $14(2.4)$ & \\
\hline & I don't know & $32(1.6)$ & $4(0.5)$ & $13(2.0)$ & $10(1.7)$ & \\
\hline \multirow{5}{*}{$\begin{array}{l}\text { I am worried about the } \\
\text { health effects of the } \\
\text { chemicals in products } \\
\text { that I use daily }\end{array}$} & $\begin{array}{l}\text { Completely } \\
\text { agree }\end{array}$ & 333 (16.4) & $268(33.5)$ & $64(10.0)$ & $1(0.2)$ & \multirow{5}{*}{$<0.001$} \\
\hline & $\begin{array}{l}\text { Somewhat } \\
\text { agree }\end{array}$ & 777 (38.3) & $364(45.4)$ & 368 (57.3) & $45(7.7)$ & \\
\hline & $\begin{array}{c}\text { Somewhat } \\
\text { disagree }\end{array}$ & $620(30.5)$ & $126(15.7)$ & $143(22.3)$ & $351(60.3)$ & \\
\hline & $\begin{array}{l}\text { Completely } \\
\text { disagree }\end{array}$ & $202(10.0)$ & $19(2.4)$ & $10(1.6)$ & $173(29.7)$ & \\
\hline & I don't know & $98(4.8)$ & $3.0(24)$ & $57(8.9)$ & $12(2.1)$ & \\
\hline \multirow{5}{*}{$\begin{array}{l}\text { I am worried about the } \\
\text { environmental effects } \\
\text { of the chemicals in } \\
\text { products that I } \\
\text { use daily }\end{array}$} & $\begin{array}{l}\text { Completely } \\
\text { agree }\end{array}$ & 495 (24.4) & $436(54.4)$ & $59(9.2)$ & $0(0.0)$ & \multirow{5}{*}{$<0.001$} \\
\hline & $\begin{array}{l}\text { Somewhat } \\
\text { agree }\end{array}$ & 904 (44.5) & $340(42.4)$ & $545(84.9)$ & $19(3.3)$ & \\
\hline & $\begin{array}{l}\text { Somewhat } \\
\text { disagree }\end{array}$ & $436(21.5)$ & $4(0.5)$ & $1(0.2)$ & 431 (74.1) & \\
\hline & $\begin{array}{l}\text { Completely } \\
\text { disagree }\end{array}$ & $116(5.7)$ & $0(0.0)$ & $0(0.0)$ & 116 (19.9) & \\
\hline & I don't know & 79 (3.9) & $21(2.6)$ & $37(5.8)$ & $16(2.7)$ & \\
\hline
\end{tabular}

Table A3. Awareness among the Finnish population of the presence of pharmaceutical residues in Finnish waterways and perceptions regarding the importance of different sources of pharmaceutical emissions into Finnish waterways in relation to gender, age, and education level $(n=2030)$.

\begin{tabular}{|c|c|c|c|c|c|c|c|c|c|c|c|}
\hline & & & \multicolumn{2}{|c|}{ Gender } & \multicolumn{4}{|c|}{ Age } & \multicolumn{3}{|c|}{ Education } \\
\hline & & All & Female & Male & $18-34$ & $35-59$ & $60-74$ & $75-79$ & $\begin{array}{l}\text { Elementary } \\
\text { School }\end{array}$ & $\begin{array}{c}\text { Upper } \\
\text { Secondary } \\
\text { Education }\end{array}$ & $\begin{array}{c}\text { Tertiary } \\
\text { Education }\end{array}$ \\
\hline \multirow{2}{*}{$\begin{array}{c}\text { Aware of phar- } \\
\text { maceuticals in } \\
\text { Finnish } \\
\text { waterways }\end{array}$} & Yes & $\begin{array}{l}1817 \\
(89.5)\end{array}$ & $\begin{array}{c}977 \\
(89.3)\end{array}$ & $\begin{array}{c}840 \\
(89.7)\end{array}$ & $\begin{array}{c}334 \\
(85.0)\end{array}$ & $\begin{array}{c}903 \\
(88.5)\end{array}$ & $\begin{array}{c}497 \\
(93.4)\end{array}$ & $\begin{array}{c}83 \\
(97.6)\end{array}$ & $\begin{array}{c}139 \\
(83.7)\end{array}$ & $\begin{array}{c}898 \\
(87.9)\end{array}$ & $\begin{array}{c}780 \\
(92.6)\end{array}$ \\
\hline & No & $\begin{array}{c}213 \\
(10.5)\end{array}$ & $\begin{array}{c}117 \\
(10.7)\end{array}$ & $\begin{array}{c}96 \\
(10.3)\end{array}$ & $\begin{array}{c}59 \\
(15.0)\end{array}$ & $\begin{array}{c}117 \\
(11.5)\end{array}$ & $\begin{array}{c}35 \\
(6.6)\end{array}$ & $\begin{array}{c}2 \\
(2.4)\end{array}$ & $\begin{array}{c}27 \\
(16.3)\end{array}$ & $\begin{array}{c}124 \\
(12.1)\end{array}$ & $\begin{array}{c}62 \\
(7.4)\end{array}$ \\
\hline$p$-value & & & \multicolumn{2}{|c|}{0.748} & \multicolumn{4}{|c|}{$<0.001$} & \multicolumn{3}{|c|}{$<0.001$} \\
\hline \multicolumn{12}{|c|}{ How much of an impact do you think the following emissions sources have regarding medicinal agents ending up in Finnish waterways: } \\
\hline \multirow{4}{*}{$\begin{array}{l}\text { Hospitals and } \\
\text { care institutions }\end{array}$} & $\begin{array}{c}\text { Major } \\
\text { impact }\end{array}$ & $\begin{array}{c}904 \\
(44.5)\end{array}$ & $\begin{array}{c}562 \\
(51.4)\end{array}$ & $\begin{array}{c}342 \\
(36.5)\end{array}$ & $\begin{array}{c}133 \\
(33.8)\end{array}$ & $\begin{array}{c}414 \\
(40.6)\end{array}$ & $\begin{array}{c}303 \\
(57.0)\end{array}$ & $\begin{array}{c}54 \\
(63.5)\end{array}$ & $\begin{array}{c}83 \\
(50.0)\end{array}$ & $\begin{array}{c}491 \\
(48.0)\end{array}$ & $\begin{array}{c}330 \\
(39.2)\end{array}$ \\
\hline & $\begin{array}{c}\text { Moderate } \\
\text { impact }\end{array}$ & $\begin{array}{c}793 \\
(39.1)\end{array}$ & $\begin{array}{c}402 \\
(36.7)\end{array}$ & $\begin{array}{c}391 \\
(41.8)\end{array}$ & $\begin{array}{c}182 \\
(46.3)\end{array}$ & $\begin{array}{c}414 \\
(40.6)\end{array}$ & $\begin{array}{c}172 \\
(32.3)\end{array}$ & $\begin{array}{c}25 \\
(29.4)\end{array}$ & $\begin{array}{c}56 \\
(33.7)\end{array}$ & $\begin{array}{c}382 \\
(37.4)\end{array}$ & $\begin{array}{c}355 \\
(42.2)\end{array}$ \\
\hline & $\begin{array}{l}\text { Minor } \\
\text { impact }\end{array}$ & $\begin{array}{c}298 \\
(14.7)\end{array}$ & $\begin{array}{c}120 \\
(11.0)\end{array}$ & $\begin{array}{c}178 \\
(19.0)\end{array}$ & $\begin{array}{c}72 \\
(18.3)\end{array}$ & $\begin{array}{c}171 \\
(16.8)\end{array}$ & $\begin{array}{c}49 \\
(9.2)\end{array}$ & $\begin{array}{c}6 \\
(7.1)\end{array}$ & $\begin{array}{c}21 \\
(12.7)\end{array}$ & $\begin{array}{c}135 \\
(13.2)\end{array}$ & $\begin{array}{c}142 \\
(16.9)\end{array}$ \\
\hline & $\begin{array}{c}\text { No } \\
\text { impact }\end{array}$ & $\begin{array}{c}35 \\
(1.7)\end{array}$ & $\begin{array}{c}10 \\
(0.9)\end{array}$ & $\begin{array}{c}25 \\
(2.7)\end{array}$ & $\begin{array}{c}6 \\
(1.5)\end{array}$ & $\begin{array}{c}21 \\
(2.1)\end{array}$ & $\begin{array}{c}8 \\
(1.5)\end{array}$ & $\begin{array}{c}0 \\
(0.0)\end{array}$ & $\begin{array}{c}6 \\
(3.6)\end{array}$ & $\begin{array}{c}14 \\
(1.4)\end{array}$ & $\begin{array}{c}15 \\
(1.8)\end{array}$ \\
\hline
\end{tabular}


Table A3. Cont.

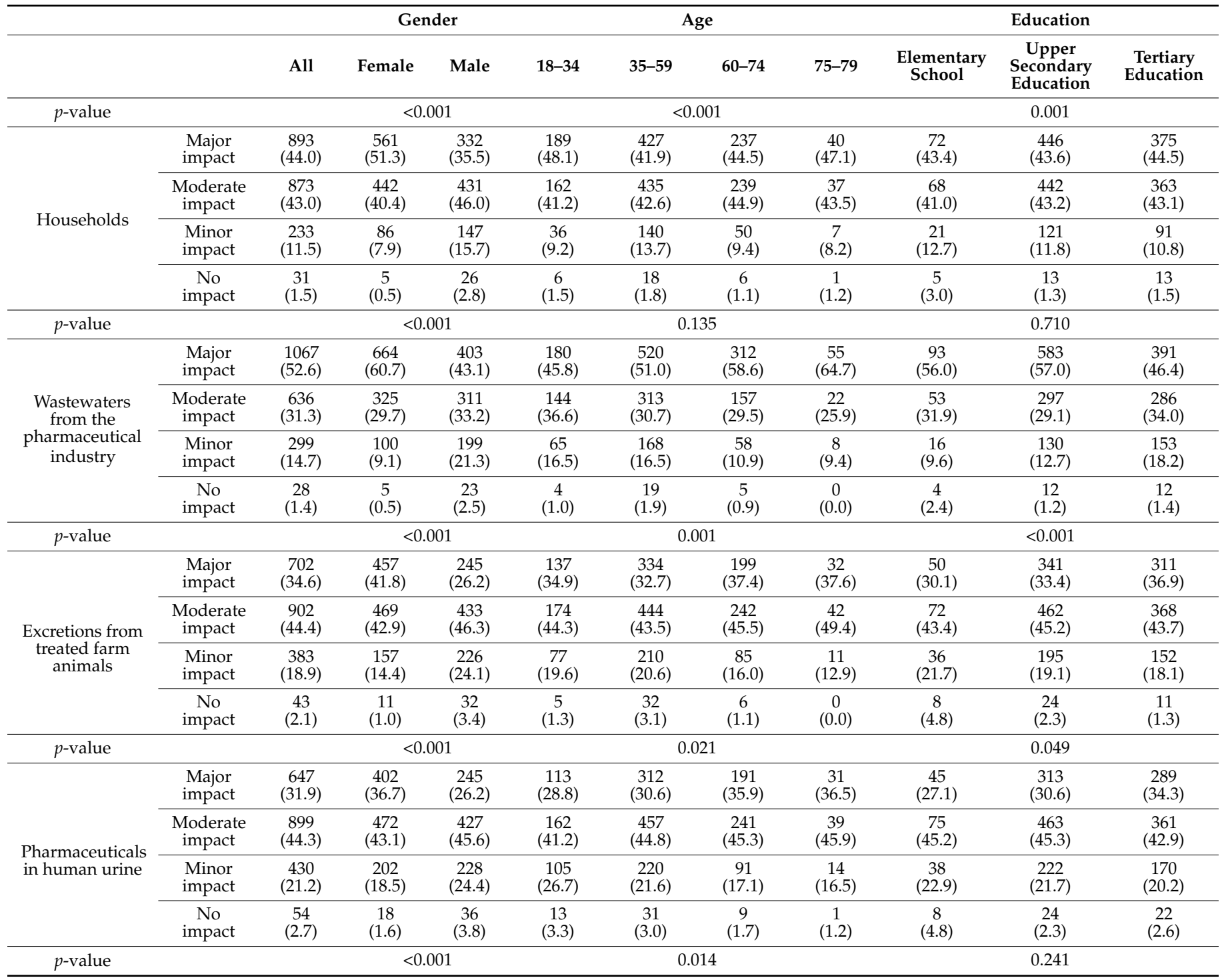

Table A4. Awareness of the presence of pharmaceutical residues in Finnish waterways among the Finnish population, and perceptions regarding the importance of different sources of pharmaceutical emissions into Finnish waterways in relation to long-term illness and use of medicines $(n=2030)$.

\begin{tabular}{|c|c|c|c|c|c|c|c|}
\hline & & \multicolumn{2}{|c|}{ Long-Term Illness } & \multicolumn{2}{|c|}{$\begin{array}{l}\text { Use of Prescription } \\
\text { Medicines during the } \\
\text { Last Week }\end{array}$} & \multicolumn{2}{|c|}{$\begin{array}{l}\text { Use of OTC Medicines } \\
\text { during the Last Week }\end{array}$} \\
\hline & & Yes & No & Yes & No & Yes & No \\
\hline \multirow{2}{*}{$\begin{array}{l}\text { Were you aware that } \\
\text { pharmaceutical residues have } \\
\text { been found in Finnish waterways? }\end{array}$} & Yes & $1198(90.3)$ & $587(88.4)$ & $1238(90.8)$ & $567(87.5)$ & 759 (88.3) & $1050(90.8)$ \\
\hline & No & $128(9.7)$ & $77(11.6)$ & $126(9.2)$ & $81(12.5)$ & $101(11.7)$ & $107(9.2)$ \\
\hline \multicolumn{2}{|l|}{$p$-value } & \multicolumn{2}{|c|}{0.179} & \multicolumn{2}{|c|}{0.024} & \multicolumn{2}{|c|}{0.068} \\
\hline \multicolumn{8}{|c|}{ How much of an impact do you think the following emissions sources have regarding medicinal agents ending up in Finnish waterways: } \\
\hline \multirow{4}{*}{ Hospitals and care institutions } & Major impact & $606(45.7)$ & $279(42.0)$ & $627(46.0)$ & $272(42.0)$ & $382(44.4)$ & $521(45.0)$ \\
\hline & $\begin{array}{l}\text { Moderate } \\
\text { impact }\end{array}$ & $521(39.3)$ & $262(39.5)$ & $529(38.8)$ & $258(39.8)$ & $353(41.0)$ & $433(37.4)$ \\
\hline & Minor impact & $177(13.3)$ & $112(16.9)$ & $189(13.9)$ & $104(16.0)$ & $117(13.6)$ & $178(15.4)$ \\
\hline & No impact & $22(1.7)$ & $11(1.7)$ & $19(1.4)$ & $14(2.2)$ & $8(0.9)$ & $25(2.2)$ \\
\hline
\end{tabular}


Table A4. Cont.

\begin{tabular}{|c|c|c|c|c|c|c|c|}
\hline & & \multicolumn{2}{|c|}{ Long-Term Illness } & \multicolumn{2}{|c|}{$\begin{array}{c}\text { Use of Prescription } \\
\text { Medicines during the } \\
\text { Last Week }\end{array}$} & \multicolumn{2}{|c|}{$\begin{array}{l}\text { Use of OTC Medicines } \\
\text { during the Last Week }\end{array}$} \\
\hline \multicolumn{2}{|l|}{$p$-value } & \multicolumn{2}{|c|}{0.163} & \multicolumn{2}{|c|}{0.194} & \multicolumn{2}{|c|}{0.062} \\
\hline \multirow{4}{*}{ Households } & Major impact & $596(44.9)$ & $282(42.5)$ & $617(45.2)$ & $272(42.0)$ & $387(45.0)$ & $502(43.4)$ \\
\hline & $\begin{array}{l}\text { Moderate } \\
\text { impact }\end{array}$ & $568(42.8)$ & $288(43.4)$ & $583(42.7)$ & $280(43.2)$ & $368(42.8)$ & $497(43.0)$ \\
\hline & Minor impact & 145 (10.9) & $84(12.7)$ & $145(10.6)$ & $86(13.3)$ & $93(10.8)$ & $140(12.1)$ \\
\hline & No impact & $17(1.3)$ & $10(1.5)$ & $19(1.4)$ & $10(1.5)$ & $12(1.4)$ & $18(1.6)$ \\
\hline \multicolumn{2}{|l|}{$p$-value } & \multicolumn{2}{|c|}{0.585} & \multicolumn{2}{|c|}{0.282} & \multicolumn{2}{|c|}{0.780} \\
\hline \multirow{4}{*}{$\begin{array}{l}\text { Wastewaters from the } \\
\text { pharmaceutical industry }\end{array}$} & Major impact & $724(54.6)$ & $326(49.1)$ & $742(54.4)$ & $320(49.4)$ & $467(54.3)$ & $597(51.6)$ \\
\hline & $\begin{array}{l}\text { Moderate } \\
\text { impact }\end{array}$ & $405(30.5)$ & $217(32.7)$ & $424(31.1)$ & 205 (31.6) & $270(31.4)$ & $360(31.3)$ \\
\hline & Minor impact & $182(13.7)$ & $110(16.6)$ & $187(13.7)$ & $108(16.7)$ & $112(13.0)$ & $184(15.9)$ \\
\hline & No impact & $15(1.1)$ & $11(1.7)$ & $11(0.8)$ & $15(2.3)$ & $11(1.3)$ & $16(1.4)$ \\
\hline \multicolumn{2}{|l|}{$p$-value } & \multicolumn{2}{|c|}{0.088} & \multicolumn{2}{|c|}{0.006} & \multicolumn{2}{|c|}{0.318} \\
\hline \multirow{4}{*}{$\begin{array}{l}\text { Excretions from treated } \\
\text { farm animals }\end{array}$} & Major impact & $460(34.7)$ & $229(34.5)$ & $479(35.1)$ & $217(33.5)$ & $306(35.6)$ & $394(34.1)$ \\
\hline & $\begin{array}{l}\text { Moderate } \\
\text { impact }\end{array}$ & $602(45.4)$ & $282(42.5)$ & $605(44.4)$ & $290(44.8)$ & $391(45.5)$ & $503(43.5)$ \\
\hline & Minor impact & $237(17.9)$ & $141(21.2)$ & $256(18.8)$ & $124(19.1)$ & $152(17.7)$ & $229(19.8)$ \\
\hline & No impact & $27(2.0)$ & $12(1.8)$ & $24(1.8)$ & $17(2.6)$ & $11(1.3)$ & $31(2.7)$ \\
\hline \multicolumn{2}{|l|}{$p$-value } & \multicolumn{2}{|c|}{0.307} & \multicolumn{2}{|c|}{0.574} & \multicolumn{2}{|c|}{0.086} \\
\hline \multirow{4}{*}{ Pharmaceuticals in human urine } & Major impact & $425(32.1)$ & $210(31.6)$ & $435(31.9)$ & $209(32.3)$ & $272(31.6)$ & $372(32.2)$ \\
\hline & $\begin{array}{l}\text { Moderate } \\
\text { impact }\end{array}$ & $586(44.2)$ & $296(44.6)$ & $602(44.1)$ & $286(44.1)$ & $367(42.7)$ & $525(54.4)$ \\
\hline & Minor impact & $281(21.2)$ & $141(21.2)$ & $293(21.5)$ & $135(20.8)$ & $198(23.0)$ & $231(20.0)$ \\
\hline & No impact & $34(2.6)$ & $17(2.6)$ & $34(2.5)$ & $18(2.8)$ & $23(2.7)$ & $29(2.5)$ \\
\hline \multicolumn{2}{|l|}{$p$-value } & \multicolumn{2}{|c|}{0.998} & \multicolumn{2}{|c|}{0.970} & \multicolumn{2}{|c|}{0.380} \\
\hline
\end{tabular}

Table A5. Opinions and attitudes concerning pharmaceuticals and the environment in relation to gender, age, and level of education of the Finnish adult population $(n=2030)$.

\begin{tabular}{|c|c|c|c|c|c|c|c|c|c|c|c|}
\hline & & & \multicolumn{2}{|c|}{ Gender } & \multicolumn{4}{|c|}{ Age } & \multicolumn{3}{|c|}{ Education } \\
\hline & & All & Female & Male & $18-34$ & $35-59$ & $60-74$ & $75-79$ & $\begin{array}{l}\text { Elementary } \\
\text { School }\end{array}$ & $\begin{array}{c}\text { Upper } \\
\text { Secondary } \\
\text { Education }\end{array}$ & $\begin{array}{c}\text { Tertiary } \\
\text { Education }\end{array}$ \\
\hline \multirow{3}{*}{$\begin{array}{l}\text { Pharmaceutical } \\
\text { residues in nature } \\
\text { pose a risk to the } \\
\text { environment }\end{array}$} & Agree & $\begin{array}{l}1814 \\
(89.4)\end{array}$ & $\begin{array}{l}1025 \\
(93.7)\end{array}$ & $\begin{array}{c}789 \\
(84.3)\end{array}$ & $\begin{array}{c}355 \\
(90.3)\end{array}$ & $\begin{array}{c}889 \\
(87.2)\end{array}$ & $\begin{array}{c}488 \\
(91.7)\end{array}$ & $\begin{array}{c}82 \\
(96.5)\end{array}$ & $\begin{array}{c}132 \\
(79.5)\end{array}$ & $\begin{array}{c}917 \\
(89.7)\end{array}$ & $\begin{array}{c}765 \\
(90.9)\end{array}$ \\
\hline & Disagree & $\begin{array}{l}108 \\
(5.3)\end{array}$ & $\begin{array}{c}24 \\
(2.2)\end{array}$ & $\begin{array}{c}84 \\
(9.0)\end{array}$ & $\begin{array}{c}15 \\
(3.8)\end{array}$ & $\begin{array}{c}69 \\
(6.8)\end{array}$ & $\begin{array}{c}22 \\
(4.1)\end{array}$ & $\begin{array}{c}2 \\
(2.4)\end{array}$ & $\begin{array}{c}16 \\
(9.6)\end{array}$ & $\begin{array}{c}52 \\
(5.1)\end{array}$ & $\begin{array}{c}40 \\
(4.8)\end{array}$ \\
\hline & $\begin{array}{l}\text { I don't } \\
\text { know }\end{array}$ & $\begin{array}{l}108 \\
(5.3)\end{array}$ & $\begin{array}{c}45 \\
(4.1)\end{array}$ & $\begin{array}{c}63 \\
(6.7)\end{array}$ & $\begin{array}{c}23 \\
(5.9)\end{array}$ & $\begin{array}{c}62 \\
(6.1)\end{array}$ & $\begin{array}{c}22 \\
(4.1)\end{array}$ & $\begin{array}{c}1 \\
(1.2)\end{array}$ & $\begin{array}{c}18 \\
(10.8)\end{array}$ & $\begin{array}{c}53 \\
(5.2)\end{array}$ & $\begin{array}{c}37 \\
(4.4)\end{array}$ \\
\hline$p$-value & & & \multicolumn{2}{|c|}{$<0.001$} & \multicolumn{4}{|c|}{0.018} & \multicolumn{3}{|c|}{0.001} \\
\hline \multirow{3}{*}{$\begin{array}{l}\text { The environmental } \\
\text { impact of medicinal } \\
\text { products is a new and } \\
\text { unfamiliar thing to me }\end{array}$} & Agree & $\begin{array}{c}531 \\
(26.2)\end{array}$ & $\begin{array}{c}276 \\
(25.2)\end{array}$ & $\begin{array}{c}255 \\
(27.2)\end{array}$ & $\begin{array}{c}126 \\
(32.1)\end{array}$ & $\begin{array}{c}273 \\
(26.8)\end{array}$ & $\begin{array}{c}117 \\
(22.0)\end{array}$ & $\begin{array}{c}15 \\
(17.6)\end{array}$ & $\begin{array}{c}59 \\
(35.5)\end{array}$ & $\begin{array}{c}279 \\
(27.3)\end{array}$ & $\begin{array}{c}193 \\
(22.9)\end{array}$ \\
\hline & Disagree & $\begin{array}{l}1444 \\
(71.1)\end{array}$ & $\begin{array}{c}793 \\
(72.5)\end{array}$ & $\begin{array}{c}651 \\
(69.6)\end{array}$ & $\begin{array}{c}253 \\
(64.4)\end{array}$ & $\begin{array}{c}713 \\
(69.9)\end{array}$ & $\begin{array}{c}408 \\
(76.7)\end{array}$ & $\begin{array}{c}70 \\
(82.4)\end{array}$ & $\begin{array}{c}99 \\
(59.6)\end{array}$ & $\begin{array}{c}709 \\
(69.4)\end{array}$ & $\begin{array}{c}636 \\
(75.5)\end{array}$ \\
\hline & $\begin{array}{l}\text { I don't } \\
\text { know }\end{array}$ & $\begin{array}{l}55 \\
(2.7)\end{array}$ & $\begin{array}{l}25 \\
(2.3)\end{array}$ & $\begin{array}{c}30 \\
(3.2)\end{array}$ & $\begin{array}{c}14 \\
(3.6)\end{array}$ & $\begin{array}{c}34 \\
(3.3)\end{array}$ & $\begin{array}{c}7 \\
(1.3)\end{array}$ & $\begin{array}{c}0 \\
(0.0)\end{array}$ & $\begin{array}{c}8 \\
(4.8)\end{array}$ & $\begin{array}{c}34 \\
(3.3)\end{array}$ & $\begin{array}{c}13 \\
(1.5)\end{array}$ \\
\hline$p$-value & & & \multicolumn{2}{|c|}{0.227} & \multicolumn{4}{|c|}{$<0.001$} & \multicolumn{3}{|c|}{$<0.001$} \\
\hline \multirow{3}{*}{$\begin{array}{l}\text { I am worried about } \\
\text { the potential } \\
\text { environmental impact } \\
\text { of medicinal products }\end{array}$} & Agree & $\begin{array}{l}1617 \\
(79.7)\end{array}$ & $\begin{array}{c}949 \\
(86.7)\end{array}$ & $\begin{array}{c}668 \\
(71.4)\end{array}$ & $\begin{array}{c}306 \\
(77.9)\end{array}$ & $\begin{array}{c}779 \\
(76.4)\end{array}$ & $\begin{array}{c}454 \\
(85.3)\end{array}$ & $\begin{array}{c}78 \\
(91.8)\end{array}$ & $\begin{array}{c}127 \\
(76.5)\end{array}$ & $\begin{array}{c}807 \\
(79.0)\end{array}$ & $\begin{array}{c}683 \\
(81.1)\end{array}$ \\
\hline & Disagree & $\begin{array}{c}316 \\
(15.6)\end{array}$ & $\begin{array}{l}104 \\
(9.5)\end{array}$ & $\begin{array}{c}212 \\
(22.6)\end{array}$ & $\begin{array}{c}66 \\
(16.8)\end{array}$ & $\begin{array}{c}188 \\
(18.4)\end{array}$ & $\begin{array}{c}58 \\
(10.9)\end{array}$ & $\begin{array}{c}4 \\
(4.7)\end{array}$ & $\begin{array}{c}28 \\
(16.9)\end{array}$ & $\begin{array}{c}164 \\
(16.0)\end{array}$ & $\begin{array}{c}124 \\
(14.7)\end{array}$ \\
\hline & $\begin{array}{l}\text { I don't } \\
\text { know }\end{array}$ & $\begin{array}{c}97 \\
(4.8)\end{array}$ & $\begin{array}{c}41 \\
(3.7)\end{array}$ & $\begin{array}{c}56 \\
(6.0)\end{array}$ & $\begin{array}{c}21 \\
(5.3)\end{array}$ & $\begin{array}{c}53 \\
(5.2)\end{array}$ & $\begin{array}{c}20 \\
(3.8)\end{array}$ & $\begin{array}{c}3 \\
(3.5)\end{array}$ & $\begin{array}{c}11 \\
(6.6)\end{array}$ & $\begin{array}{c}51 \\
(5.0)\end{array}$ & $\begin{array}{c}35 \\
(4.2)\end{array}$ \\
\hline
\end{tabular}


Table A5. Cont.

\begin{tabular}{|c|c|c|c|c|c|c|c|c|c|c|c|}
\hline & & & \multicolumn{2}{|c|}{ Gender } & \multicolumn{4}{|c|}{ Age } & \multicolumn{3}{|c|}{ Education } \\
\hline & & All & Female & Male & $18-34$ & $35-59$ & $60-74$ & $75-79$ & $\begin{array}{l}\text { Elementary } \\
\text { School }\end{array}$ & $\begin{array}{c}\text { Upper } \\
\text { Secondary } \\
\text { Education }\end{array}$ & $\begin{array}{c}\text { Tertiary } \\
\text { Education }\end{array}$ \\
\hline$p$-value & & & \multicolumn{2}{|c|}{$<0.001$} & \multicolumn{4}{|c|}{$<0.001$} & \multicolumn{3}{|c|}{0.530} \\
\hline \multirow{3}{*}{$\begin{array}{l}\text { I am worried about } \\
\text { the impact on human } \\
\text { health of } \\
\text { pharmaceutical } \\
\text { residues in the } \\
\text { environment }\end{array}$} & Agree & $\begin{array}{c}1545 \\
(76.1)\end{array}$ & $\begin{array}{c}898 \\
(82.1)\end{array}$ & $\begin{array}{c}647 \\
(69.1)\end{array}$ & $\begin{array}{c}271 \\
(69.0) \\
\end{array}$ & $\begin{array}{c}753 \\
(73.8) \\
\end{array}$ & $\begin{array}{c}446 \\
(83.8) \\
\end{array}$ & $\begin{array}{c}75 \\
(88.2) \\
\end{array}$ & $\begin{array}{c}121 \\
(72.9) \\
\end{array}$ & $\begin{array}{c}792 \\
(77.5) \\
\end{array}$ & $\begin{array}{c}632 \\
(75.1) \\
\end{array}$ \\
\hline & Disagree & $\begin{array}{c}395 \\
(19.5)\end{array}$ & $\begin{array}{c}152 \\
(13.9)\end{array}$ & $\begin{array}{c}243 \\
(26.0)\end{array}$ & $\begin{array}{c}101 \\
(25.7)\end{array}$ & $\begin{array}{c}220 \\
(21.6)\end{array}$ & $\begin{array}{c}67 \\
(12.6)\end{array}$ & $\begin{array}{c}7 \\
(8.2)\end{array}$ & $\begin{array}{c}31 \\
(18.7)\end{array}$ & $\begin{array}{c}186 \\
(18.2)\end{array}$ & $\begin{array}{c}178 \\
(21.1)\end{array}$ \\
\hline & $\begin{array}{l}\text { I don't } \\
\text { know }\end{array}$ & $\begin{array}{c}90 \\
(4.4)\end{array}$ & $\begin{array}{c}44 \\
(4.0)\end{array}$ & $\begin{array}{c}46 \\
(4.9)\end{array}$ & $\begin{array}{c}21 \\
(5.3)\end{array}$ & $\begin{array}{c}47 \\
(4.6)\end{array}$ & $\begin{array}{c}19 \\
(3.6)\end{array}$ & $\begin{array}{c}3 \\
(3.5)\end{array}$ & $\begin{array}{c}14 \\
(8.4)\end{array}$ & $\begin{array}{c}44 \\
(4.3)\end{array}$ & $\begin{array}{c}32 \\
(3.8)\end{array}$ \\
\hline$p$-value & & & \multicolumn{2}{|c|}{$<0.001$} & \multicolumn{4}{|c|}{$<0.001$} & \multicolumn{3}{|c|}{0.050} \\
\hline \multirow{3}{*}{$\begin{array}{l}\text { Physicians prescribing } \\
\text { a medicinal product } \\
\text { should consider the } \\
\text { environmental impact } \\
\text { of the product where } \\
\text { possible }\end{array}$} & Agree & $\begin{array}{c}1202 \\
(59.2)\end{array}$ & $\begin{array}{c}697 \\
(63.7)\end{array}$ & $\begin{array}{c}505 \\
(54.0)\end{array}$ & $\begin{array}{c}216 \\
(55.0)\end{array}$ & $\begin{array}{c}552 \\
(54.1)\end{array}$ & $\begin{array}{c}368 \\
(69.2)\end{array}$ & $\begin{array}{c}66 \\
(77.6)\end{array}$ & $\begin{array}{c}94 \\
(56.6)\end{array}$ & $\begin{array}{c}598 \\
(58.5)\end{array}$ & $\begin{array}{c}510 \\
(60.6)\end{array}$ \\
\hline & Disagree & $\begin{array}{c}609 \\
(30.0)\end{array}$ & $\begin{array}{c}271 \\
(24.8)\end{array}$ & $\begin{array}{c}338 \\
(36.1)\end{array}$ & $\begin{array}{c}133 \\
(33.8)\end{array}$ & $\begin{array}{c}348 \\
(34.1)\end{array}$ & $\begin{array}{c}116 \\
(21.8)\end{array}$ & $\begin{array}{c}12 \\
(14.1)\end{array}$ & $\begin{array}{c}47 \\
(28.3)\end{array}$ & $\begin{array}{c}307 \\
(30.0)\end{array}$ & $\begin{array}{c}255 \\
(30.3)\end{array}$ \\
\hline & $\begin{array}{l}\text { I don't } \\
\text { know }\end{array}$ & $\begin{array}{c}219 \\
(10.8)\end{array}$ & $\begin{array}{c}126 \\
(11.5)\end{array}$ & $\begin{array}{c}93 \\
(9.9)\end{array}$ & $\begin{array}{c}44 \\
(11.2)\end{array}$ & $\begin{array}{c}120 \\
(11.8)\end{array}$ & $\begin{array}{c}48 \\
(9.0)\end{array}$ & $\begin{array}{c}7 \\
(8.2)\end{array}$ & $\begin{array}{c}25 \\
(15.1)\end{array}$ & $\begin{array}{c}117 \\
(11.4)\end{array}$ & $\begin{array}{c}77 \\
(9.1)\end{array}$ \\
\hline$p$-value & & & \multicolumn{2}{|c|}{$<0.001$} & \multicolumn{4}{|c|}{$<0.001$} & \multicolumn{3}{|c|}{0.196} \\
\hline \multirow{3}{*}{$\begin{array}{l}\text { Package leaflets in } \\
\text { medicine packs } \\
\text { describe the correct } \\
\text { way to dispose of the } \\
\text { medicine }\end{array}$} & Agree & $\begin{array}{l}1598 \\
(78.7)\end{array}$ & $\begin{array}{c}847 \\
(77.4)\end{array}$ & $\begin{array}{c}751 \\
(80.2)\end{array}$ & $\begin{array}{c}278 \\
(70.7)\end{array}$ & $\begin{array}{c}784 \\
(76.9)\end{array}$ & $\begin{array}{c}459 \\
(86.3)\end{array}$ & $\begin{array}{c}77 \\
(90.6)\end{array}$ & $\begin{array}{c}131 \\
(78.9)\end{array}$ & $\begin{array}{c}827 \\
(80.9)\end{array}$ & $\begin{array}{c}640 \\
(76.0)\end{array}$ \\
\hline & Disagree & $\begin{array}{c}228 \\
(11.2) \\
\end{array}$ & $\begin{array}{c}130 \\
(11.9)\end{array}$ & $\begin{array}{c}98 \\
(10.5) \\
\end{array}$ & $\begin{array}{c}57 \\
(14.5) \\
\end{array}$ & $\begin{array}{c}118 \\
(11.6) \\
\end{array}$ & $\begin{array}{c}48 \\
(9.0) \\
\end{array}$ & $\begin{array}{c}5 \\
(5.9) \\
\end{array}$ & $\begin{array}{c}22 \\
(13.3)\end{array}$ & $\begin{array}{c}102 \\
(10.0)\end{array}$ & $\begin{array}{c}104 \\
(12.4)\end{array}$ \\
\hline & $\begin{array}{l}\text { I don't } \\
\text { know }\end{array}$ & $\begin{array}{c}204 \\
(10.0)\end{array}$ & $\begin{array}{c}117 \\
(10.7)\end{array}$ & $\begin{array}{c}87 \\
(9.3)\end{array}$ & $\begin{array}{c}58 \\
(14.8)\end{array}$ & $\begin{array}{c}118 \\
(11.6)\end{array}$ & $\begin{array}{c}25 \\
(4.7)\end{array}$ & $\begin{array}{c}3 \\
(3.5)\end{array}$ & $\begin{array}{c}13 \\
(7.8)\end{array}$ & $\begin{array}{c}93 \\
(9.1)\end{array}$ & $\begin{array}{c}98 \\
(11.6)\end{array}$ \\
\hline$p$-value & & & \multicolumn{2}{|c|}{0.303} & \multicolumn{4}{|c|}{$<0.001$} & \multicolumn{3}{|c|}{0.083} \\
\hline \multirow{3}{*}{$\begin{array}{l}\text { It is important that I } \\
\text { can recycle the } \\
\text { packaging material of } \\
\text { medicines } \\
\text { (outer and inner } \\
\text { packs) appropriately }\end{array}$} & Agree & $\begin{array}{c}1751 \\
(86.3) \\
\end{array}$ & $\begin{array}{c}1019 \\
(93.1)\end{array}$ & $\begin{array}{c}732 \\
(78.2) \\
\end{array}$ & $\begin{array}{c}337 \\
(85.8) \\
\end{array}$ & $\begin{array}{c}847 \\
(83.0) \\
\end{array}$ & $\begin{array}{c}488 \\
(91.7) \\
\end{array}$ & $\begin{array}{c}79 \\
(92.9) \\
\end{array}$ & $\begin{array}{c}141 \\
(84.9)\end{array}$ & $\begin{array}{c}870 \\
(85.1)\end{array}$ & $\begin{array}{c}740 \\
(87.9)\end{array}$ \\
\hline & Disagree & $\begin{array}{c}216 \\
(10.6)\end{array}$ & $\begin{array}{c}46 \\
(4.2)\end{array}$ & $\begin{array}{c}170 \\
(18.2)\end{array}$ & $\begin{array}{c}43 \\
(10.9)\end{array}$ & $\begin{array}{c}131 \\
(12.8)\end{array}$ & $\begin{array}{c}37 \\
(7.0)\end{array}$ & $\begin{array}{c}5 \\
(5.9)\end{array}$ & $\begin{array}{c}18 \\
(10.8)\end{array}$ & $\begin{array}{c}118 \\
(11.5)\end{array}$ & $\begin{array}{c}80 \\
(9.5)\end{array}$ \\
\hline & $\begin{array}{l}\text { I don't } \\
\text { know }\end{array}$ & $\begin{array}{c}63 \\
(3.1) \\
\end{array}$ & $\begin{array}{c}29 \\
(2.7) \\
\end{array}$ & $\begin{array}{c}34 \\
(3.6) \\
\end{array}$ & $\begin{array}{c}13 \\
(3.3) \\
\end{array}$ & $\begin{array}{c}42 \\
(4.1) \\
\end{array}$ & $\begin{array}{c}7 \\
(1.3) \\
\end{array}$ & $\begin{array}{c}1 \\
(1.2) \\
\end{array}$ & $\begin{array}{c}7 \\
(4.2) \\
\end{array}$ & $\begin{array}{c}34 \\
(3.3) \\
\end{array}$ & $\begin{array}{c}22 \\
(2.6) \\
\end{array}$ \\
\hline$p$-value & & & \multicolumn{2}{|c|}{$<0.001$} & \multicolumn{4}{|c|}{$<0.001$} & \multicolumn{3}{|c|}{0.442} \\
\hline \multirow{3}{*}{$\begin{array}{l}\text { It is important that I } \\
\text { know pharmaceutical } \\
\text { companies act in an } \\
\text { environmentally } \\
\text { friendly way and in } \\
\text { accordance with the } \\
\text { conditions for } \\
\text { sustainable } \\
\text { development }\end{array}$} & Agree & $\begin{array}{c}1672 \\
(82.4)\end{array}$ & $\begin{array}{c}953 \\
(87.1)\end{array}$ & $\begin{array}{c}719 \\
(76.8)\end{array}$ & $\begin{array}{c}314 \\
(79.9)\end{array}$ & $\begin{array}{c}809 \\
(79.3)\end{array}$ & $\begin{array}{c}472 \\
(88.7)\end{array}$ & $\begin{array}{c}77 \\
(90.6)\end{array}$ & $\begin{array}{c}128 \\
(77.1)\end{array}$ & $\begin{array}{c}847 \\
(82.9)\end{array}$ & $\begin{array}{c}697 \\
(82.8)\end{array}$ \\
\hline & Disagree & $\begin{array}{c}235 \\
(11.6)\end{array}$ & $\begin{array}{c}79 \\
(7.2)\end{array}$ & $\begin{array}{c}156 \\
(16.7)\end{array}$ & $\begin{array}{c}54 \\
(13.7)\end{array}$ & $\begin{array}{c}136 \\
(13.3)\end{array}$ & $\begin{array}{c}40 \\
(7.5)\end{array}$ & $\begin{array}{c}5 \\
(5.9)\end{array}$ & $\begin{array}{c}23 \\
(13.9)\end{array}$ & $\begin{array}{c}115 \\
(11.3)\end{array}$ & $\begin{array}{c}97 \\
(11.5)\end{array}$ \\
\hline & $\begin{array}{l}\text { I don't } \\
\text { know }\end{array}$ & $\begin{array}{c}123 \\
(6.1)\end{array}$ & $\begin{array}{c}62 \\
(5.7)\end{array}$ & $\begin{array}{c}61 \\
(6.5)\end{array}$ & $\begin{array}{c}25 \\
(6.4)\end{array}$ & $\begin{array}{c}75 \\
(7.4)\end{array}$ & $\begin{array}{c}20 \\
(3.8)\end{array}$ & $\begin{array}{c}3 \\
(3.5)\end{array}$ & $\begin{array}{c}15 \\
(9.0)\end{array}$ & $\begin{array}{c}60 \\
(5.9)\end{array}$ & $\begin{array}{c}48 \\
(5.7)\end{array}$ \\
\hline$p$-value & & & \multicolumn{2}{|c|}{$<0.001$} & \multicolumn{4}{|c|}{$<0.001$} & \multicolumn{3}{|c|}{0.391} \\
\hline \multirow{3}{*}{$\begin{array}{l}\text { Today, wastewater } \\
\text { treatment ensures that } \\
\text { no pharmaceuticals } \\
\text { end up in natural } \\
\text { waters from sewers }\end{array}$} & Agree & $\begin{array}{c}560 \\
(27.6)\end{array}$ & $\begin{array}{c}291 \\
(26.6)\end{array}$ & $\begin{array}{c}269 \\
(28.7)\end{array}$ & $\begin{array}{c}96 \\
(24.4)\end{array}$ & $\begin{array}{c}287 \\
(28.1)\end{array}$ & $\begin{array}{c}146 \\
(27.4)\end{array}$ & $\begin{array}{c}31 \\
(36.5)\end{array}$ & $\begin{array}{c}65 \\
(39.2)\end{array}$ & $\begin{array}{c}308 \\
(30.1)\end{array}$ & $\begin{array}{c}187 \\
(22.2)\end{array}$ \\
\hline & Disagree & $\begin{array}{c}1189 \\
(58.6)\end{array}$ & $\begin{array}{c}626 \\
(57.2) \\
\end{array}$ & $\begin{array}{c}563 \\
(60.1) \\
\end{array}$ & $\begin{array}{c}219 \\
(55.7) \\
\end{array}$ & $\begin{array}{c}596 \\
(58.4) \\
\end{array}$ & $\begin{array}{c}327 \\
(61.5) \\
\end{array}$ & $\begin{array}{c}47 \\
(55.3)\end{array}$ & $\begin{array}{c}76 \\
(45.8) \\
\end{array}$ & $\begin{array}{c}579 \\
(56.7) \\
\end{array}$ & $\begin{array}{c}534 \\
(63.4) \\
\end{array}$ \\
\hline & $\begin{array}{l}\text { I don't } \\
\text { know }\end{array}$ & $\begin{array}{c}281 \\
(13.8)\end{array}$ & $\begin{array}{c}177 \\
(16.2)\end{array}$ & $\begin{array}{c}104 \\
(11.1)\end{array}$ & $\begin{array}{c}78 \\
(19.8)\end{array}$ & $\begin{array}{c}137 \\
(13.4)\end{array}$ & $\begin{array}{c}59 \\
(11.1)\end{array}$ & $\begin{array}{c}7 \\
(8.2)\end{array}$ & $\begin{array}{c}25 \\
(15.1)\end{array}$ & $\begin{array}{c}135 \\
(13.2)\end{array}$ & $\begin{array}{c}121 \\
(14.4)\end{array}$ \\
\hline$p$-value & & & \multicolumn{2}{|c|}{0.004} & & & & & & $<0.001$ & \\
\hline $\begin{array}{l}\text { Finland should set an } \\
\text { example for other }\end{array}$ & Agree & $\begin{array}{c}1522 \\
(75.0)\end{array}$ & $\begin{array}{c}920 \\
(84.1) \\
\end{array}$ & $\begin{array}{c}602 \\
(64.3) \\
\end{array}$ & $\begin{array}{c}319 \\
(81.2) \\
\end{array}$ & $\begin{array}{c}736 \\
(72.2) \\
\end{array}$ & $\begin{array}{c}399 \\
(75.0) \\
\end{array}$ & $\begin{array}{c}68 \\
(80.0) \\
\end{array}$ & $\begin{array}{c}109 \\
(65.7) \\
\end{array}$ & $\begin{array}{c}742 \\
(72.6) \\
\end{array}$ & $\begin{array}{c}671 \\
(79.7) \\
\end{array}$ \\
\hline $\begin{array}{l}\text { countries in reducing } \\
\text { the environmental }\end{array}$ & Disagree & $\begin{array}{c}367 \\
(18.1)\end{array}$ & $\begin{array}{c}101 \\
(9.2)\end{array}$ & $\begin{array}{c}266 \\
(28.4)\end{array}$ & $\begin{array}{c}49 \\
(12.5)\end{array}$ & $\begin{array}{c}203 \\
(19.9)\end{array}$ & $\begin{array}{c}101 \\
(19.0)\end{array}$ & $\begin{array}{c}14 \\
(16.5)\end{array}$ & $\begin{array}{c}40 \\
(24.1)\end{array}$ & $\begin{array}{c}204 \\
(20.0)\end{array}$ & $\begin{array}{c}123 \\
(14.6)\end{array}$ \\
\hline $\begin{array}{l}\text { impact of medicinal } \\
\text { products }\end{array}$ & $\begin{array}{l}\text { I don't } \\
\text { know }\end{array}$ & $\begin{array}{l}141 \\
(6.9)\end{array}$ & $\begin{array}{c}73 \\
(6.7)\end{array}$ & $\begin{array}{c}68 \\
(7.3)\end{array}$ & $\begin{array}{c}25 \\
(6.4)\end{array}$ & $\begin{array}{c}81 \\
(7.9)\end{array}$ & $\begin{array}{l}32 \\
(6.0)\end{array}$ & $\begin{array}{c}3 \\
(3.5)\end{array}$ & $\begin{array}{c}17 \\
(10.2)\end{array}$ & $\begin{array}{c}76 \\
(7.4)\end{array}$ & $\begin{array}{c}48 \\
(5.7)\end{array}$ \\
\hline$p$-value & & & & & & & & & & $<0.001$ & \\
\hline
\end{tabular}


Table A6. Opinions and attitudes concerning pharmaceuticals and the environment in relation to long-term illness and use of medicines among the Finnish adult population $(n=2030)$.

\begin{tabular}{|c|c|c|c|c|c|c|c|}
\hline & & \multicolumn{2}{|c|}{ Long-Term Illness } & \multicolumn{2}{|c|}{$\begin{array}{l}\text { Use of Prescription Medicines } \\
\text { during the Last Week }\end{array}$} & \multicolumn{2}{|c|}{$\begin{array}{l}\text { Use of OTC Medicines } \\
\text { during the Last Week }\end{array}$} \\
\hline & & Yes & No & Yes & No & Yes & No \\
\hline \multirow{3}{*}{$\begin{array}{l}\text { Pharmaceutical residues in nature pose a } \\
\text { risk to the environment }\end{array}$} & Agree & $1193(90.0)$ & $593(89.3)$ & $1220(89.4)$ & $582(89.8)$ & $767(89.2)$ & $1039(89.8)$ \\
\hline & Disagree & $64(4.8)$ & $37(5.6)$ & $70(7.1)$ & $34(5.2)$ & $49(5.7)$ & $57(4.9)$ \\
\hline & I don't know & $69(5.2)$ & $34(5.1)$ & $74(5.4)$ & $32(4.9)$ & $44(5.1)$ & $61(5.3)$ \\
\hline$p$-value & & \multicolumn{2}{|c|}{0.774} & \multicolumn{2}{|c|}{0.898} & \multicolumn{2}{|c|}{0.740} \\
\hline \multirow{3}{*}{$\begin{array}{l}\text { The environmental impact of medicinal } \\
\text { products is a new and unfamiliar thing to } \\
\text { me }\end{array}$} & Agree & $338(25.5)$ & $185(27.9)$ & $358(26.2)$ & $166(25.6)$ & $238(27.7)$ & $287(24.8)$ \\
\hline & Disagree & $952(71.8)$ & $462(69.6)$ & $970(71.1)$ & $464(71.6)$ & $600(69.8)$ & $839(72.5)$ \\
\hline & I don't know & $36(2.7)$ & $17(2.6)$ & $36(2.6)$ & $18(2.8)$ & $22(2.6)$ & $31(2.7)$ \\
\hline$p$-value & & \multicolumn{2}{|c|}{0.524} & \multicolumn{2}{|c|}{0.945} & \multicolumn{2}{|c|}{0.348} \\
\hline \multirow{3}{*}{$\begin{array}{l}\text { I am worried about the potential } \\
\text { environmental impact of medicinal } \\
\text { products }\end{array}$} & Agree & $1059(79.9)$ & $535(80.6)$ & $1089(79.8)$ & $517(79.8)$ & $701(78.4)$ & $907(78.4)$ \\
\hline & Disagree & $207(15.6)$ & 99 (14.9) & $216(15.8)$ & $96(14.8)$ & $192(16.6)$ & $192(16.6)$ \\
\hline & I don't know & $60(4.5)$ & $30(4.5)$ & $59(4.3)$ & $35(5.4)$ & $58(5.0)$ & $58(5.0)$ \\
\hline$p$-value & & \multicolumn{2}{|c|}{0.919} & \multicolumn{2}{|c|}{0.501} & \multicolumn{2}{|c|}{0.227} \\
\hline \multirow{3}{*}{$\begin{array}{l}\text { I am worried about the impact on human } \\
\text { health of pharmaceutical residues in the } \\
\text { environment }\end{array}$} & Agree & $1036(78.1)$ & $485(73.0)$ & $1057(77.5)$ & 479 (73.9) & $677(78.7)$ & $860(74.3)$ \\
\hline & Disagree & $236(17.8)$ & $150(22.6)$ & $248(18.2)$ & $140(21.6)$ & $150(17.4)$ & $241(20.8)$ \\
\hline & I don't know & $54(4.1)$ & $29(4.4)$ & $59(4.3)$ & $29(4.5)$ & $33(3.8)$ & $56(4.8)$ \\
\hline$p$-value & & \multicolumn{2}{|c|}{0.033} & \multicolumn{2}{|c|}{0.180} & \multicolumn{2}{|c|}{0.071} \\
\hline \multirow{3}{*}{$\begin{array}{l}\text { Physicians prescribing a medicinal } \\
\text { product should consider the } \\
\text { environmental impact of the product } \\
\text { where possible }\end{array}$} & Agree & $791(59.7)$ & 395 (59.5) & 811 (59.5) & $383(59.1)$ & $500(58.1)$ & $695(60.1)$ \\
\hline & Disagree & $392(29.6)$ & $204(30.7)$ & $404(29.6)$ & $197(30.4)$ & $268(31.2)$ & $338(29.2)$ \\
\hline & I don't know & $143(10.8)$ & $65(9.8)$ & $149(10.9)$ & $68(10.5)$ & $92(10.7)$ & $124(10.7)$ \\
\hline$p$-value & & \multicolumn{2}{|c|}{0.733} & \multicolumn{2}{|c|}{0.916} & \multicolumn{2}{|c|}{0.627} \\
\hline \multirow{3}{*}{$\begin{array}{l}\text { Package leaflets in medicine packs } \\
\text { describe the correct way to dispose of the } \\
\text { medicine }\end{array}$} & Agree & $1053(79.4)$ & $519(78.2)$ & $1078(79.0)$ & $509(78.5)$ & $653(75.9)$ & $938(81.1)$ \\
\hline & Disagree & 148 (11.2) & $73(11.0)$ & $157(11.5)$ & $66(10.2)$ & $112(13.0)$ & $114(9.9)$ \\
\hline & I don't know & $125(9.4)$ & $72(10.8)$ & $129(9.5)$ & 73 (11.3) & $95(11.0)$ & $105(9.1)$ \\
\hline$p$-value & & 0. & & & & & \\
\hline & Agree & 1157 (87.3) & $572(86.1)$ & $1186(87.0)$ & $554(85.5)$ & $744(86.5)$ & $999(86.3)$ \\
\hline packaging material of medicines (outer & Disagree & $130(9.8)$ & $74(11.1)$ & $138(10.1)$ & $74(11.4)$ & $94(10.9)$ & $119(10.3)$ \\
\hline oacks) app & I don't know & $39(2.9)$ & $18(2.7)$ & $40(2.9)$ & $20(3.1)$ & $22(2.6)$ & $39(3.4)$ \\
\hline$p$-value & & 0. & & & & & \\
\hline It is important that I know pharmaceutical & Agree & $1094(82.5)$ & $554(83.4)$ & $1125(82.5)$ & $535(82.6)$ & $709(82.4)$ & $953(82.4)$ \\
\hline $\begin{array}{l}\text { companies act in an environmentally } \\
\text { friendly way and in accordance with the }\end{array}$ & Disagree & $155(11.7)$ & $71(10.7)$ & $155(11.4)$ & $77(11.9)$ & $100(11.6)$ & $134(11.6)$ \\
\hline conditions for sustainable development & I don't know & $77(5.8)$ & $39(5.9)$ & $84(6.2)$ & $36(5.6)$ & $51(5.9)$ & $70(6.1)$ \\
\hline$p$-value & & 0.8 & & & & & \\
\hline Today, wastewater treatment ensures that & Agree & $373(28.1)$ & $180(27.1)$ & $381(27.9)$ & $174(26.9)$ & $228(26.5)$ & $327(28.3)$ \\
\hline no medicinal agents end up in natural & Disagree & $780(58.8)$ & $389(58.6)$ & $793(58.1)$ & $389(60.0)$ & $502(58.4)$ & $682(58.9)$ \\
\hline we & I don't know & $173(13.0)$ & $95(14.3)$ & $190(13.9)$ & $85(13.1)$ & $130(15.1)$ & $148(12.8)$ \\
\hline$p$-value & & 0.7 & & & & & \\
\hline & Agree & $985(74.3)$ & $517(77.9)$ & $1016(74.5)$ & $495(76.4)$ & $669(77.8)$ & $845(73.0)$ \\
\hline countries in reducing the environmental & Disagree & $247(18.6)$ & $108(16.3)$ & $253(18.5)$ & $110(17.0)$ & $143(16.6)$ & $221(19.1)$ \\
\hline 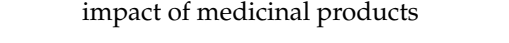 & I don't know & $94(7.1)$ & $39(5.9)$ & $95(7.0)$ & $43(6.6)$ & $48(5.6)$ & $91(7.9)$ \\
\hline$p$-value & & 0.2 & & & & & \\
\hline
\end{tabular}

\section{References}

1. Aus der Beek, T.; Weber, F.-A.; Bergmann, A.; Hickmann, S.; Ebert, I.; Hein, A.; Küster, A. Pharmaceuticals in the environmentGlobal occurrences and perspectives. Environ. Toxicol. Chem. 2016, 35, 823-835. [CrossRef] [PubMed]

2. UNESCO. International Initiative on Water Quality: Promoting Scientific Research, Knowledge Sharing, Effective Technology and Policy Approaches to Improve Water Quality for Sustainable Development; UNESCO: Paris, France, 2015.

3. European Commission. European Union Strategic Approach to Pharmaceuticals in the Environment; COM (2019) 128 Final; European Commission: Brussels, Belgium, 2019.

4. Green, R.E.; Newton, I.; Shultz, S.; Cunningham, A.A.; Gilbert, M.; Pain, D.J.; Prakash, V. Diclofenac poisoning as a cause of vulture population declines across the Indian subcontinent. J. Appl. Ecol. 2004, 41, 793-800. [CrossRef] 
5. Vajda, A.M.; Barber, L.B.; Gray, J.L.; Lopez, E.M.; Bolden, A.M.; Schoenfuss, H.L.; Norris, D.O. Demasculinization of male fish by wastewater treatment plant effluent. Aquat. Toxicol. 2011, 103, 213-221. [CrossRef] [PubMed]

6. BIO Intelligence Service; Executive Agency for Health and Consumers. Study on the Environmental Risks of Medicinal Products; BIO Intelligence Service: Neuilly-sur-Seine, France, 2013.

7. Shao, J.; Unal, E. What do consumers value more in green purchasing? Assessing the sustainability practices from demand side of business. J. Clean. Prod. 2019, 209, 1473-1483. [CrossRef]

8. Milanesi, M.; Runfola, A.; Guercini, S. Pharmaceutical industry riding the wave of sustainability: Review and opportunities for future research. J. Clean. Prod. 2020, 261, 121204. [CrossRef]

9. Bound, J.P.; Voulvoulis, N. Household disposal of pharmaceuticals as a pathway for aquatic contamination in the United kingdom. Environ. Health Perspect. 2005, 113, 1705-1711. [CrossRef] [PubMed]

10. Bound, J.P.; Kitsou, K.; Voulvoulis, N. Household disposal of pharmaceuticals and perception of risk to the environment. Environ. Toxicol. Pharmacol. 2006, 21, 301-307. [CrossRef] [PubMed]

11. Persson, M.; Sabelström, E.; Gunnarsson, B. Handling of unused prescription drugs—Knowledge, behavior and attitude among Swedish people. Environ. Int. 2009, 35, 771-774. [CrossRef] [PubMed]

12. Vatovec, C.; Van Wagoner, E.; Evans, C. Investigating sources of pharmaceutical pollution: Survey of over-the-counter and prescription medication purchasing, use, and disposal practices among university students. J. Environ. Manag. 2017, 198, 348-352. [CrossRef] [PubMed]

13. Alajärvi, L.; Martikainen, J.; Timonen, J. Are pharmaceuticals considered as an environmental risk? Knowledge and views of the Finnish public regarding pharmaceuticals and the environment. Pharm. Period. DOSIS 2020, 36, 368-383.

14. Dohle, S.; Campbell, V.E.A.; Arvai, J.L. Consumer-perceived risks and choices about pharmaceuticals in the environment: A cross-sectional study. Environ. Health 2013, 12, 45. [CrossRef] [PubMed]

15. Götz, K.; Courtier, A.; Stein, M.; Strelau, L.; Sunderer, G.; Vidaurre, R.; Winker, M. Risk Perception of Pharmaceutical Residues in the Aquatic Environment and Precautionary Measures. Manag. Emerg. Public Health Issues Risks 2019, 189-224. [CrossRef]

16. Petrie, K.J.; Sivertsen, B.; Hysing, M.; Broadbent, E.; Moss-Morris, R.; Eriksen, H.R.; Ursin, H. Thoroughly modern worries: The relationship of worries about modernity to reported symptoms, health and medical care utilization. J. Psychosom. Res. 2001, 51, 395-401. [CrossRef]

17. Kollmuss, A.; Agyeman, J. Mind the Gap: Why do people act environmentally and what are the barriers to pro-environmental behavior? Environ. Educ. Res. 2002, 8, 239-260. [CrossRef]

18. Whitburn, J.; Linklater, W.; Abrahamse, W. Meta-analysis of human connection to nature and proenvironmental behavior. Conserv. Biol. 2020, 34, 180-193. [CrossRef] [PubMed]

19. Frontpage-SUDDEN. Available online: https://sudden.fi/en/ (accessed on 3 August 2021).

20. Statistics Finland. Available online: https://www.tilastokeskus.fi/tup/suoluk/suoluk_vaesto_en.html (accessed on 4 November 2020). (In Finnish)

21. Healthcare in Finland-EU-Healthcare.fi. Available online: https://www.eu-healthcare.fi/healthcare-in-finland/ (accessed on 18 June 2021).

22. Terveys-Tulosraportti 2020-FinSote-THL. Available online: http://www.terveytemme.fi/finsote/2020/terveys.html (accessed on 18 June 2021). (In Finnish)

23. Rastas, P.; Saastamoinen, L.; Sarparanta, T.; Voipio, T. Finnish Statistics on Medicines; Kela: Helsinki, Finland, 2020.

24. Pharma Industry Finland. Available online: https:/ / www.laaketeollisuus.fi/uutishuone/tilastot.html (accessed on 4 January 2021). (In Finnish)

25. The Association of Finnish Pharmacies. Available online: https://www.apteekkariliitto.fi/apteekkitieto/apteekit-numeroina html (accessed on 4 November 2020). (In Finnish)

26. Louhisalmi, M.; Alajärvi, L.; Martikainen, J.; Timonen, J. Finns return pharmaceutical waste to pharmacy—Survey on the means of disposal of unused and expired medicines by the Finnish adult population. Pharm. Period. DOSIS 2020, 36, $384-397$.

27. European Commission. Special Eurobarometer 501: Attitudes of European Citizens towards the Environment; European Union: Brussels, Belgium, 2020.

28. Suomen Ympäristökeskus > Iäkkäämmät Kantavat Nuoria Enemmän Huolta Luonnosta, Ilmastonmuutos ja Roskaantuminen Suomalaisten Mielestä Suurimmat Uhkatekijät. Available online: https://www.syke.fi/fi-FI/Ajankohtaista/Iakkaammat_ kantavat_nuoria_enemman_huolt(47263) (accessed on 18 June 2021). (In Finnish)

29. Kotchen, M.; Kallaos, J.; Wheeler, K.; Wong, C.; Zahller, M. Pharmaceuticals in wastewater: Behavior, preferences, and willingness to pay for a disposal program. J. Environ. Manag. 2009, 90, 1476-1482. [CrossRef] [PubMed]

30. European Commission. Special Eurobarometer 468: Attitudes of European Citizens towards the Environment; European Union: Brussels, Belgium, 2017.

31. Muthén, L.K.; Muthén, B.O. Statistical Analysis with Latent Variables: User's Guide; Muthén \& Muthén: Los Angeles, CA, USA, 1998.

32. Finnish National Board on Research Integrity. Finnish National Board on Research Integrity Guidelines: The Ethical Principles of Research with Human Participants and Ethical Review in the Human Sciences in Finland; Finnish National Board on Research Integrity (TENK): Helsinki, Finland, 2019. 
33. Vieno, N.; Karlsson, S.; Aysto, L.; Mehtonen, J.; Sikanen, T.; Kärkkäinen, R.; Yli-Kauhaluoma, J.; Nystén, T. Lääkeaineiden Ympäristö-Luokittelun Käyttöönoton Mahdollisuudet Suomessa-Alternatives of Introducing an Environmental Classification System of Pharmaceuticals in Finland; Finnish Environment Institute: Helsinki, Finland, 2019.

34. Slovic, P. Perception of risk. Science 1987, 236, 280-285. [CrossRef] [PubMed]

35. Agarwal, V.; Halli, P.; Helin, S.; Tesfaye, F.; Lundström, M. Electrohydraulic Fragmentation of Aluminum and Polymer Fractions from Waste Pharmaceutical Blisters. ACS Sustain. Chem. Eng. 2020, 8, 4137-4145. [CrossRef]

36. Sarnola, K.; Hämeen-Anttila, K.; Jyrkkä, J. Finnish Medicines Barometer 2019: Description of the Data and Data Collection of the Population Survey; FIMEA: Helsinki, Finland, 2019.

37. Silvennoinen, E.; Hämeen-Anttila, K.; Jauhonen, H.-M.; Jyrkkä, J. Finnish Medicines Barometer 2017: Description of the Data and Data Collection of the Population Survey; FIMEA: Helsinki, Finland, 2018.

38. Tolonen, H. Towards the High Quality of Population Health Surveys: Standardization and Quality Control; National Public Health Institute: Helsinki, Finland, 2006.

39. Haverland, M.; de Ruiter, M.; Van de Walle, S. Agenda-setting by the European Commission. Seeking public opinion? J. Eur. Public Policy 2016, 25, 327-345. [CrossRef]

40. Höpner, M.; Jurczyk, B. How the Eurobarometer Blurs the Line between Research and Propaganda. 2015. Available online: https:/ / papers.ssrn.com/sol3/papers.cfm?abstract_id=2681038 (accessed on 18 June 2021). 